NBER WORKING PAPER SERIES

\author{
REGULATION - THE CORRIDOR TO LIBERALIZATION: \\ THE EXPERIENCE OF THE ISRAELI PHONE MARKET 1984-2005 \\ Reuben Gronau \\ Working Paper 12617 \\ http://www.nber.org/papers/w12617
}

\author{
NATIONAL BUREAU OF ECONOMIC RESEARCH \\ 1050 Massachusetts Avenue \\ Cambridge, MA 02138 \\ October 2006
}

I would like to thank Neil Gandel and David Genesove and two unanimous referees for their helpful comments. The views expressed herein are those of the author(s) and do not necessarily reflect the views of the National Bureau of Economic Research.

(C) 2006 by Reuben Gronau. All rights reserved. Short sections of text, not to exceed two paragraphs, may be quoted without explicit permission provided that full credit, including $\odot$ notice, is given to the source. 
Regulation - the Corridor to Liberalization: The Experience of the Israeli Phone Market 1984-2005 Reuben Gronau

NBER Working Paper No. 12617

October 2006

JEL No. K2,L43,L5,L51,L96

\begin{abstract}
$\underline{\text { ABSTRACT }}$
An important part of the literature on regulatory economics is based on the US experience, where a well-established regulator faces a privately owned monopoly. It is sometimes forgotten that this model does not apply in many places where a newly established regulator faces a government owned, or a newly privatized, company. It definitely does not apply to the case of the Israeli communication industry where the government serves as regulator and at the same time is the owner of the wireline monopolist. The paper follows the regulatory experience of the Israeli communication industry over the last 20 years, analyzing its impact on consumers' welfare, the monopoly's profitability and its productivity. Though the Israeli institutions may look to a Western observer today as unique they were quite common in most of the developed economies prior to the wave of privatizations and deregulation in the 90s. The lessons learned from the Israeli experience have, however, more than a historic interest, and may be relevant for the regulatory process in general.
\end{abstract}

\author{
Reuben Gronau \\ Department of Economics \\ Hebrew University \\ Mount Scopus, Jerusalem 91905 \\ Israel \\ and NBER \\ msreuben@olive.mscc.huji.ac.il
}




\section{Regulation - the Corridor to Liberalization: The Experience of the Israeli Phone Market 1984-2005}

\section{A. Introduction}

The deregulation and liberalization of the public utility industries are among the most dramatic institutional changes that have taken place in the Western economies in the last two decades. Industries that for decades had been regarded as prototypes of natural monopolies have been opened to competition, and the role of the regulator was downgraded to a secondary role. The reforms that started in the mid-80s with the deregulation of the U.S. transport industry (trucking, railroad, and airlines), spread across the Atlantic, and expanded to the telecommunication and electricity industries. Economists, who often spearheaded this move, called for the abolition of regulation whenever competition could be trusted. Building on their experience with the U.S. transport and telecommunication industries they blamed regulation for creating incentives for misallocation of resources (i.e., the Averch-Johnson effect), leading to non-optimal quality, and weakening the incentives to increase efficiency. Regulators were depicted as prone to be captured by the regulated monopolies, and regulation was regarded as the biggest obstacle to the introduction of competition

The road to competition was not always smooth - the California electricity reforms and the British railroad privatization are often cited as examples of its pitfalls. Admittedly, economists often failed in predicting all the obstacles lying on the way. Still the prevailing mood in the economic literature concerning regulation was that of disapproval. Only few economists bothered to ask themselves the extent to which the US experience applicable also to other environments. After all, most of the US public utilities industries are unique in being controlled since their establishment by private interests, whereas the ownership of their European counterparts was entrusted for many decades to the public sector. Similarly, most of the US regulating bodies are well entrenched institutions, dating back to the pre-WWII era, whereas in other parts of the world the regulating bodies have a much shorter history, and are, perhaps, less affected by the "signs of old age" which the US regulating bodies are accused of. This realization has led many economists to study the experience of regulating bodies outside the US so as to provide a more rounded picture of the strength and weaknesses of the regulatory process.

The Israeli regulatory experience of the telecommunication industry may seem unique. For the last twenty years the regulatory process has been under government control, and up to 
quite recently the major phone company was government owned and had full monopolistic power on the wireline market. Conventional wisdom would have regarded this combination as a sure prescription for inefficiency of various kinds. Still, at the beginning of the $21^{\text {st }}$ century the Israeli consumers enjoy a wide variety of advanced communication services at some of the lowest rates of the Western economies. This record is especially remarkable given the state of the industry twenty years ago when Bezeq, the Israeli phone operator, was first incorporated. The thriving state of the industry and the incumbent, on one hand, and the prevailing low phone rates, on the other, can be traced to the special mix of liberalization and regulation policies adopted by the government for the last two decades.

This paper tells the story of the Israeli industry, focusing on the interaction between the regulated firm and its regulators. ${ }^{1}$ The lessons to be derived from the Israeli experience have, definitely, a historic interest. After all, though the Israeli institutional environment may seem unique on the background of the institutional setup prevailing in the Western economies today, it was quite common prior to the wave of privatizations and deregulation in the 90s. They seem, however, to be relevant for the regulatory process in general, and specifically for two central themes in the new economics of regulation literature: the impact of the institutional environment on the regulatory outcomes, and the effect of the asymmetry in information on the regulatory regime.

The paper opens with a description of the Israeli communication market, the institutional background and the changes in the size of the market and its composition. A discussion of the regulatory regime is followed by three sections evaluating its impact of on three key parameters- consumers' welfare, the monopoly's profitability and production efficiency. The paper closes with lessons one can learn from the Israeli experience in light of the economic theory of regulation.

\section{B. The Israeli Communication Market.}

\section{Institutional Background}

Bezeq, the Israeli phone company, was established in 1984. The State of Israel inherited in 1948 the responsibilities for the provision of phone services from the British regime, and for the next 36 years it followed the UK model granting statutory monopoly to the Post Office (later renamed the Ministry of Communication). It was only in the early 80s that it was 
recognized that the governmental structure lacks the flexibility required in order to provide a growing modern economy with adequate telecommunication services. Bezeq was established as a fully owned government-company, and when the government decided six years later to issue part of the stock on the Israeli stock-market it still preserved its status as majority stock holder.

Bezeq was born into bad times. Since 1977 the Israeli economy had been inflicted by an uncontainable inflation, the CPI increasing between 50 and 370 percent annually. Bezeq was born in the final phases of that period, but it took the government another year (and another 300 percent inflation) before it mustered the courage to adopt severe anti-inflationary steps to halt this ruinous process. The years of fast inflation were characterized by halfhearted measures to slow down the price increase. Two of these policy measures affected the phone services directly: the price-freeze imposed on government services, and the cut of government investment. Bezeq's first task was to catch up with the ever-widening excess demand for phone lines, created by the cuts in the Ministry of Communication's investment budgets in previous years.

Given the dire state of the communication market hardly anybody protested when Bezeq was granted a license that effectively transferred the monopoly rights enjoyed by the government to the new company ${ }^{2}$, but as the waiting lines for phone services shrunk, more and more voices were heard calling for structural reform in the communication market. The new mood was affected by a deepening awareness that the monopolistic structure of the infrastructure industries constituted an impediment to growth, by an attempt to reduce the role of government in the economy, and by the wave of structural reforms that had swept these industries abroad

Several governmental committees in the late ' 80 s recommended replacing the allencompassing franchise of Bezeq by a series of permits regulating its activity in the separate telecommunication markets. It took, however, five years for these recommendations to be adopted. In 1994 the government revoked Bezeq's general license, and the company received separate permits to operate in the domestic market (local and intercity calls), the international

\footnotetext{
${ }^{1}$ Some aspects of the reform in the Israeli telecommunication market have been discussed by Gandel (1999) and Levi-Faur (1999). The reforms and the regulatory regime in the Israeli public utility industries are discussed in an early paper of mine (Gronau, 2002).

${ }^{2}$ The broad definitions used in the license to describe Bezeq's monopolistic rights can be attributed to the fact that the license was formulated by members of the Ministry of Communication legal department who were assigned to move to the new company.
} 
calls market, the mobile phone markets, and equipment sales and installations. To prevent cross-subsidization between these services and assure any potential competitor open access to Bezeq lines, the permits for operating in the mobile, international and equipment market were granted to Bezeq subsidiaries, establishing a structural separation between the monopoly operating in the domestic market and its subsidiaries' operation in the other markets.

The first market opened to competition was the cellular phone market. The activity in this market was monopolized by a Bezeq's subsidiary, Pelephone, and the government preferred to open the market in a controlled fashion, where for the first years it would be operated by a duopoly. ${ }^{3}$

Of critical importance to the future development of this market was the procedure adopted to select the new competitor. The competitor was chosen in an open bid, where the main criterion was the rate structure. The winner of the bid, the Cellcom company, offered an unprecedented rate in the Western mobile phone market at the time - 2.5 US cents per minute ${ }^{4}$. The duopoly period lasted for about 3 years. These were years of unprecedented growth of the mobile phone market. In the July 1997 the government declared another bid for the selection of a third competitor. Realizing the growth potential of the market, the government changed the main criterion for the selection of the winner, offering the "prize" to the highest bidder for the permit. The winner, the Partner company got the permit for the price of 400 million US dollars 5 . The technology adopted by the new entrant (GSM) and an aggressive marketing strategy allowed it to compete successfully with its entrenched rivals. ${ }^{6}$

Though the opening of the mobile phone market had definitely the most far-reaching implications for the communication market, and was most probably the most dramatic structural reform in the Israeli public utilities sector, it had little political repercussions ${ }^{7}$. This was not the case when in October 1995 the government published its auction for two new

\footnotetext{
${ }^{3}$ The length of the duopoly period was defined as 5 years, or the period required for the market to expand to 200 thousand subscribers, whichever came first.

${ }^{4}$ Cellcom was a joint venture of a leading international phone company (Bell South), an international banking group (the Safra group) and a leading domestic investment company. The financial backing, the professional know-how and the barriers on entry imposed by the government (even if only for a limited period) clearly contributed the low price offred in the bid.

${ }^{5}$ Partner is a subsidiary of the Hutchinson group

${ }^{6}$ The technology was dictated by the terms of the bid.

${ }^{7}$ In 1993 mobile phones contributed only 3 percent of Bezeq's income and consequently the move encountered only mild opposition from Bezeq's management and workers' union.
} 
operators in the international calls market, which were to share the market with Bezeq's subsidiary - "Bezeq International".

The international calls market served for years as a main source of income used to subsidize local access. Setting a high rate for outgoing calls allowed Bezeq to charge high rates for its interconnect services for the incoming international calls. Since the rate for an outgoing call from Israel was substantially higher than that prevailing abroad, the Israeli international calls market was characterized by an imbalance of traffic, the number of incoming calls exceeding significantly that of outgoing calls. Thus, the revenues from the interconnect charges for incoming international calls had become one of the main sources of finance of Bezeq's domestic activities. The regulator, though aware of the allocative inefficiency, did little to change this system of cross-subsidies from the foreign customer to the Israeli one.

Given the high share of Bezeq's income originating in international calls (in 1995 it constituted a third of Bezeq's income), the opening of the market to competition did not go unopposed. Bezeq's management, and in particular its workers' union, threatened to deny the new entrants access to the company's lines, unless Bezeq is compensated for its loss of income. The government succumbed to this pressure and set up a scheme that would prevent a sharp decline in the company's profitability. ${ }^{8}$

The winners in the international providers' bid were chosen again on the basis of the lowest rates. The two companies that won the bid offered to lower the rates of outgoing calls, on average, by 70 percent. The incumbent was prevented by the regulator from matching these prices. The new entrants started their operation in July 1997 and within 2 months the incumbent lost more than 40 percent of the market. At this point the restrictions on minimum rates were removed, and the incumbent was allowed to compete freely. Within few years the share of the competitors stabilized, each company serving about one-third of the market.

The original government plan called for the opening of the domestic market to competition by 1999. A series of government committees were unanimous in recommending facility-based competition as the base of the reform, rejecting "unbundling" as a too time consuming process. To prevent cherry-picking, new competitors focusing on the business

\footnotetext{
${ }^{8}$ The scheme consisted of three parts: 1) a levy was imposed on the international providers; 2) the government reduced the special tax imposed on phone services, and 3) the government decelerated the rate of decline of domestic phone rates.
} 
sector, new entrants were obligated to provide virtually universal service throughout most of the country. ${ }^{9}$

The only operators who could meet these harsh entry requirements were the TV cable companies whose network was spread all over the country, and who enjoyed, at the time, remarkable profitability. But the scheme never materialized. A disagreement between the Ministries of Finance, Justice and Communication on whether the cable companies should be charged for the special permit to engage in two-way phone service resulted in a delay of the cable companies' entry. By the time the controversy was settled, the opportunity for opening the market to competition was gone. The rich resources commanded by the cable companies were squandered on buyouts of their competitors at inflated prices, and communication companies lost their popularity in the capital market. ${ }^{10}$

Only after a new government committee recommended in 2002 to alleviate many of the previous entry barriers, allowing operators providing a limited array of services in a limited number of districts to obtain operator permits, did the merged cable company enter the domestic phone market.

The declining popularity of communication companies in the capital market hindered not only the liberalization of the domestic fixed line market, but also the privatization of Bezeq. It took the government several years before it was able to sell its controlling interests in the company to a group of private investors. In May 2005 the company was finally sold in an open bid, its price set at 3.1 billion US dollars.

\section{The Development of the Communication Market}

When Bezeq was established in 1984 the number of direct lines was 1.04 million. At the time 220 thousand waited to be connected to the network. Within six years the company succeeded in cutting the number of waiting customers to 20 thousand, increasing the number of lines to 1.63 million. The penetration rate increased from 80 to 83 percent of residential households. The fast growth continued at the same rate throughout the first half of the 90s (Table 1). The

\footnotetext{
${ }^{9}$ Many of the large business companies handled their internal communication (for example the communication between the bank headquarters and the branches) through lines rented from Bezeq. This type of business did not contribute, however, to competition.

${ }^{10}$ Bezeq contributed to this result. At the urging of the government it entered the multi-channel TV market offering satellite services. The cut-throat competition that followed the entry of the satellite company accelerated the depletion of the cable companies' resources, leading one of them to the brink of bankruptcy.
} 
fast growth of the economy accompanying the mass immigration from the former Soviet Union, led to an expansion of the network at a rate exceeding 7 percent annually. The expansion in the network led, in turn, to an annual increase of traffic of over 10 percent.

The fast growth lasted for dozen years, and came to a stop only in 1996. The slowdown (Table 2) can be again be traced to macro factors - the slowdown of the economy (and, in particular, an unprecedented recession in the construction industry), but it is partly explained by the fast increasing popularity of the mobile phone. The rate of growth of fixed lines slowed down to an annual rate of 3 percent, and though the growth of traffic kept up at the previous pace (i.e., at an annual rate of 9.4 percent), it underwent a drastic change in composition. Land to Land (LTL) traffic (in terms of minutes) shrunk at a rate of 2.5 percent, and the whole growth is explained by the growth of internet traffic and calls originating or terminating in the mobile and international networks.

The changes in the composition of Bezeq's traffic reflect the dramatic impact the structural changes had on the shape of the market following the opening of the mobile phone market to competition. The aggressive pricing policy adopted by Cellcom changed completely the image of the mobile service and with it the size of the potential market. Motorola, which started the service in 1987, aimed its services at a select fraction of the business community. The high rates charged for the service made it a luxury, catering to the rich. In 1993, at the eve of Cellcom's entry into the market, the number of Pelephone subscribers did not exceed 100 thousand - less than 5 percent of the fixed lines operated by Bezeq. Within three years, the number of subscribers increased ten-fold. ${ }^{11}$ The entry of Partner inaugurated a new wave of expansion. In the years 1996-2001 the number of subscribers to the mobile network increased at an annual rate of 36.5 percent, a rate unprecedented in the history of the durablegoods markets in Israel (table 3). By the end of 1999 the number of subscribers to the mobile phone network equaled that of the fixed-line, and by 2002 it surpassed it by more than onehalf.

The fast growth in the number of subscribers is reflected in the composition of traffic. In 1996 nine out of ten calls (in terms of minutes) originated in a fixed-line phone. By 2001

\footnotetext{
${ }^{11}$ Pelephone tried to emanate the image of a leader in terms of service quality, but had to bow to the price pressure and lower its prices by one third. A series of technical difficulties left its marketing policy in shambles, and it lost its dominating position to Cellcom, and few years later found itself trailing even behind the newcomer, Partner.
} 
this number dropped to two-thirds. Mobile to mobile (MTM) calls which in 1996 constituted a miniscule share of the market (3 percent), contributed one quarter of the traffic by 2001 .

Declining prices resulted in a faster growth of the international calls market relative to the domestic market even prior to its opening to competition (the international market growing at an annual rate of 14 percent). The entry of the new companies accelerated this process, but its major impact was on the direction of traffic. The sharp cut of the rates of outgoing calls led to a traffic reversal (Figure 1). Whereas prior to 1997 outgoing calls constituted less than 40 percent of international traffic, they captured 60 percent of the market once it opened to competition.

\section{The Regulatory Regime 1990-2002.}

The tariff regime in the communication market in the late 80 s suffered from all the shortcomings afflicting the other Israeli public utility industries: a tariff system based on perfect pass-through ('cost-plus'), an arbitrary rate structure and multi-body regulators. Efficiency ranked relatively low in the government's list of priorities, and this attitude changed only little when the government changed its role from direct provider to the owner of the phone company. The government also preserved its hold of the regulatory system: everyday regulation of the new company was left with the Ministry of Communication, but any change in phone rates required the consent of both the Minister of Communication and the Minister of Finance, as well as the final approval of the Finance Committee of the parliament.

The rate structure reflected the distributional priorities of the owners and the regulators. As in other places, the residential sector was given preference over the business sector. Access was subsidized by traffic- the fixed monthly user-fee being set at a level substantially lower than the costs associated with the local loop. The profit margins from traffic increased with distance: international calls were the most profitable, followed by inter-city and local calls. The involvement of the Parliamentary Finance Committee in the regulatory process assured that distributional considerations would continue to play an important role in price setting also after Bezeq became a business oriented firm.

Bezeq did not have enough time to recover from the impact of the hyper-inflation when it was hit by the fallout of the program to halt inflation. The 1985 program called for a price

freeze of government services, and Bezeq saw for the next three years its meager profits 
eroding. The erosion of profits brought Bezeq to the doors of the regulator in request of a reevaluation of the tariff regime to restore its profitability.

The recommendations to open the communication market to competition were accompanied by a recommendation to establish an independent professional regulating body (similar to OFTEL). This recommendation was never approved. Thus, when Bezeq asked for a tariff reevaluation the government settled for an alternative scheme. The role of periodic tariff reevaluation was delegated to an ad-hoc public committee consisting of representatives of the regulating ministries, independent experts and public representatives. This scheme became the mode of operation for the following fifteen years. The 1988 committee was followed by three additional ones: in 1993, 1997 and 2002. The committees had an advisory status (their recommendations had to be approved by the Ministers and the parliamentary committee), but with the years they gained ever increasing independence. ${ }^{12}$

The first committee was asked to set the level of tariffs, determine the length of the tariff review period, establish the formula for rate adjustments during the review period, and eliminate cross- subsidies. The terms of reference of the 1997 and 2002 committees were expanded, following the liberalization of the mobile and international calls markets, to incorporate also the setting of interconnect tariffs.

Following the British example, the first public committee recommended that the "Passthrough" rate-setting procedure be replaced by "Price-cap." The shift, however, turned out to be gradual, and the method employed continued to be a mixture of Price-cap and of the Rate of Return (ROR) methods. Following the Price-cap prescription, the regulatory review period was set at 4-5 years, and the rate adjustment followed the RPI-X. formula. The Israeli scheme deviated, however, from the OFTEL model in two important aspects: the mechanism of setting the average rate and the flexibility in setting the individual rates. Whereas the Oftel was committed to a gradual change in the average phone rates through changes in the adjustment factor X (Spiller and Vogelsang, 1996), the Israeli ad-hoc review committees

\footnotetext{
${ }^{12}$ The increased independence is reflected in the committees' composition. The first committee was headed by a representative of one of the regulating bodies (the director general of the Ministry of Finance) and a representative of Bezeq served as a voting member. The next committee was headed already by a public representative, and Bezeq's representative was relegated to the status of an "observer". In the following committees the head was a public representative, and Bezeq's representatives appeared before the committee as witnesses only. The smaller representation of the regulating and regulated bodies contributed to the committees' image of impartiality and to the public's (and Government's) acceptance of their recommendations.
} 
employed a two-stage mechanism: a discrete change at the beginning of each review period, and a gradual change throughout the period $(\mathrm{X}) .{ }^{13}$ Furthermore, in contrast to the British system, the regulated company was not allowed any flexibility in the setting of individual rates.

The discrete change in the average rate required a detailed calculation of the monopoly's "excess profits" and "inefficiency" at the end of each review period. These, in turn, called for a periodic readjustment of the rate of return given the dynamic changes in the competitive structure of the industry. Disbarring the firm from setting the individual rates meant that they had to be set by the committee itself.

Table 4 summarizes the main parameters of the ad-hoc committees' recommendations. The changes in these parameters reflect the changes in the economic-technological environment in which the regulated company operated as well as changes affecting the regulator: the dynamic process of accumulation of information, and the changing political constraints faced by the committees ${ }^{14}$.

The first committee's recommendations for the initial rates level reflect its limited base of information and its attempt to gain Bezeq's approval for the new rate setting procedure. The committee adopted Bezeq's 1998 cost accounts as the base for its tariff, foregoing any adjustments. Bezeq's depreciated assets were used as the base for the calculation of capital costs, and no attempt was made to distinguish between assets regarded as "used and useful", and those which do not contribute to production. When the next committee had to decide on the initial rate level for the second review period (1994-1998) it set the normative costs (i.e. the "allowed" costs) employing its predecessor's adjustment formula. It distinguished between expenditures that the company can control in the short run (e.g., wage and salary, and other operating costs) and expenditures which the company can affect only in the long run (e.g., the costs of debt and the interconnect charges for international outgoing calls), and applied the adjustment formula to the "controllable" part, accepting the other part as given. The following committees abandoned this distinction, adopting the trajectory of normative costs set by their predecessors.

To set the trajectory of normative costs one has to know potential for increased productivity. The first committee was aware of Bezeq's gross inefficiency, but again the lack of accurate information led it to adopt a conservative estimate. The low rates of adjustment

\footnotetext{
${ }^{13}$ A similar method as been adopted by the UK electricity regulator (OFFER) in 1994, and was later used by other regulators in the UK and elsewhere.
} 
during the first review period 1990-1993 ( $\mathrm{X}=3 \%$ for the first two years and 3.5\% thereafter) were, at least partially, intended to make the new regulatory regime more acceptable to the monopoly and its workers. These considerations did not affect the second committee when it raised the adjustment rate to $X=6.5 \%$, a rate that, with the exception of OFTEL, was higher than any of the rates adopted by European regulators at the time ${ }^{15}$. The third committee had access to much more detailed information than its predecessors. Bezeq's costing system showed a sharp decline in its equipment prices. The committee estimated that the rate of decline was 10-12 percent annually. The fast decline is explained both by technological improvements in the switching equipment and the fiber-optic network, and by increased competition among suppliers. The committee recommended that the adjustment rate for the third review period be set at $X=7 \%$. Finally, the fourth committee being aware of the slowdown in Bezeq's growth and its continuous effort to cut costs settled for an adjustment rate of $X=3.5 \%$, with an in-built mechanism that corrects this factor according to output growth.

When the Price-cap procedure was first proposed there were hopes that it would relieve the regulator from the problematic calculation of the normative rate of return. Given the fast changes in Bezeq's competitive environment, these hopes proved unrealistic in the Israeli context. The calculation of this rate reflects also the committees' increased access to information. The first committee set the normative rate of return was at $8.5 \%$. Since the committee could not reach agreement about the adequate rate it was set by Minister of Communication. The second committee preserved this rate, but the third committee, noting the fast growth in mobile traffic and expecting the fixed line service to open to competition soon, raised the to 10.5 percent. Neither of these committees based its evaluation on a detailed study. When the fourth committee (2002) decided to readdress the issue it used for the first time a CAPM model based on 12 years of Bezeq's experience in the Israeli stock market, leading it to conclude that, given a normative equity-debt ratio of 40:60, the proper (beforetax) rate of return should be 13 percent, and the average price of capital (WACC) - 8.5 percent (the after-tax WACC being 5.43 percent). ${ }^{16}$

\footnotetext{
${ }^{14}$ This section is written on the basis of the reports prepared by the four committees.

${ }^{15}$ This rate exceeded by far any rate applied to the tariffs of other public utilities in Israel, and was partly intended to erode Bezeq's excess profitability.

${ }^{16}$ The committee estimated the value of $\beta$ to be in the range of $0.45-0.54$, and the leveraged $\beta$ to be $0.7-0.83$. Bezeq's value of $\beta$ for the years preceding 2000 was found to be equal to 0.7 , but following the disenchantment of the capital market from the performance of the telecommunication companies
} 
The changes in the trajectory of the normative costs and the changes in Bezeq's growth of output and profitability are reflected in the different rates of tariff change (the Po adjustment) at the beginning of each review period. Whereas the first committee recommended a price hike of 15 percent, the second committee recommended an average rate cut of 10 percent, the third - a cut of 10.5 percent and the fourth- a cut of 5.5 percent. It is noteworthy that the second committee's calculations showed that the rate should have been reduced by 16 percent, but it hesitated to recommend such a large cut, in apprehension that it would be unacceptable to the politicians.

One of the main challenges facing the committees was the construction of a cost-based tariff system. In the absence of a reliable costing system there was little the first committee could do about it ${ }^{17}$. It took a while before an adequate costing system was established at the initiation of the Ministry of Communication, which appointed a committee of experts to carry out this task.

The committee estimated that if monthly fees were to cover the direct access costs, they would have to be raised by a factor of 6 , which would allow a reduction of 33-40 percent in call rates. The second review committee (1993), being aware of the parliament Finance Committee's sensitivity to the distributional impact of such an extreme change, adopted a gradual approach recommending that every reduction in the call rates would be accompanied by an identical increase in the user fee.

The committee recommended that the rates of outgoing international calls be reduced at a rate faster than domestic calls ${ }^{18}$. Bezeq, in an attempt to reduce the attractiveness of entry into the international market, hastened to oblige, reducing the rates even faster than suggested by the committee, and slowing the reduction in domestic rates.

The new costing system, and its updates by Bezeq, allowed the third committee (1997), for the first time, to completely overhaul the rate structure. It computed the "Long Run Incremental Costs" (LRIC) as the sum of the average capital costs (at replacement value) and

(including cable TV) it jumped to 1.7 The jump reflects not merely a change of mood but was caused to a large extent by the heavy losses of Bezeq's subsidiaries (the mobile company, the international provider, and, first and foremost, the satellite TV company) The committee had, therefore, to estimate what would have been Bezeq's value of $\beta$ if it had confined itself to domestic service only.

${ }^{17}$ The committee conjectured that the international and long-distance intercity calls subsidize the local and regional calls. Its report does not even mention access as the service that is most heavily subsidized.

${ }^{18}$ The committee recommended that the special tax imposed on phone calls be reduced to that purpose. 
the average direct operating costs. Since the "LRIC" of all services summed up only to twothirds of the normative (i.e., the "allowed") $\operatorname{costs}^{19}$ the committee had to decide how to allocate the overheads. It rejected the Ramsey pricing principle in favor of a proportionate markup, imposing on all services, with the exception of telephony, a markup of 50\%. Ramsey pricing would have created a special problem in the case of telephony, since it meant higher markups on access than on traffic, something that would have been completely unacceptable to the parliamentary committee ${ }^{20}$. Consequently, the committee recommended only a modest increase in the monthly fee (12 percent) to cover the access LRIC, and all the phone service overheads were charged to traffic, resulting in call rate that were 3.3 times their LRIC $^{21}$.

The high markup on domestic calls raised the problem of the appropriate markup on interconnect calls. The Ministry of Communication rules established that the interconnect rates paid by the mobile phone and the international calls companies should be negotiated directly between the involved parties, but given the frequent failure of these negotiations the rates were often set by the Ministry itself. This process resulted in a myriad of rates, the rate paid by each operator depending on his bargaining power or the pressure he could exert on the Minister. The committee set for the first time a uniform rate for all operators, a rate based on Bezeq's domestic rates. ${ }^{22}$ Given the 220 percent markup on domestic calls the committee found ECPR pricing to be unacceptable. Arguing that the terminating call in Bezeq's lines use only one section of the local loop (rather than two) it was concluded that interconnect calls should carry only half the markup (i.e., 110 percent). The lower markup translated into a reduction of interconnect rates of 60 percent, the new rates complying with the recommendations of the OECD.

\footnotetext{
${ }^{19}$ The difference is explained by common costs (given the small fraction of operating costs that can be assigned to specific outputs) and the difference between the assets' replacement values and their historical costs.

${ }^{20}$ Applying a 50 percent markup to access direct costs would have meant a jump in user fees of twothirds.

${ }^{21}$ The direct costs of access were estimated to be more than 3 times those of traffic. The "share" of access in common costs was, therefore more than 1.5 times the direct costs of traffic. This ratio leads to the "astronomous" markup on traffic. However, in spite of the high markup, traffic rates were cut sharply. Given the average rate cut of $10.5 \%$ and the increase in the monthly user fees, the tariffs of domestic calls were reduced by one- third.

${ }^{22}$ The rate varied with the hours of the day (peak and off-peak hours) and whether the operator used a local or an inter-city connection.
} 
Bezeq's original rate structure distinguished between three time slots (peak, interim and off-peak hours), and three distance ranges (local, regional and intercity). The committee recommended that this system be simplified but left the details to Bezeq's initiative. Goaded by the rate structure of the mobile operators, Bezeq adopted a uniform rate for the whole country, a rate that varied only between peak and off-peak hours. At the same time it moved to have its tariffs based on continuous measurement instead of discrete units. ${ }^{23}$

Given the major overhaul of Bezeq's tariff structure the fourth committee (2002) introduced only minor changes. It raised the user's fee by 15 percent, pursuing the previous committee's policy of rebalancing; it abolished the minimum charge to increase transparency ${ }^{24}$, and given the increased traffic in off-peak hours it reduced the difference in rates between peak and off-peak calls ${ }^{25}$. Both the rebalancing between access and traffic and between off-peak and peak contributed to the reduction in cross-subsidies between the business and the residential sector.

An outsider may blame the committees for excessive cautiousness. These accusations are not completely unfounded. The committees were aware of their advisory status, and that their recommendations required the approval of the Ministers and the parliamentary committee. Consequently, they may have shunned away from recommendations that they feared might look extreme, in order to preserve their own credibility. To what extent were these worries justified? Examining the recommendations' acceptance rates reveals an interesting pattern. The political level always adopted the recommendations concerning the rate cuts at the entry to a new review period. However, in response to Bezeq's warnings that future rate cuts would undermine the company's financial stability, the political level consistently reduced the adjustment rate $(\mathrm{X}){ }^{26}$ Surprisingly, the ostensibly most controversial recommendations-

${ }^{23}$ According to the old system the calls were measured in terms of "units." The price of a unit was fixed, and its length (in terms of seconds) varied between peak and off-peak hours and between local and inter-city calls.

${ }^{24}$ The minimum charge was a remnant of the "unit" charging system (see fn.16). It was equivalent to the rate for a 1.6 minute call during peak hours, and a 9-minute call during off-peak. As a result the marginal tariff during the off-peak hours applied only to one-eighth of the traffic.

${ }^{25}$ The rate for peak hours was cut by 25 percent and for off peak only by 8 percent.

${ }^{26}$ When the second committee recommended an adjustment rate of $6.5 \%$ the Ministers approved only $6 \%$, which was reduced, when the international market was opened to competition, to $3.5 \%$; the third committee recommended an adjustment rate of $7 \%$, but the Ministers approved only $6 \%$, which was reduced later to $3.5 \%$, when Bezeq claimed that its output did not keep up with the committee's forecasts; the fourth committee was much more conservative with its adjustment rate (3.5\%), but still it was cut to $2.5 \%$. 
those concerning rebalancing, had a perfect acceptance record. The weak opposition the recommendation to raise user fees met in parliament can be attributed to the gradual process, the modest increases in the user fees each time, and the fact that it was accompanied throughout by a reduction in the tariffs of traffic, so that most users enjoyed a reduction in their phone bills ${ }^{27}$.

\section{The Change in Tariffs 1990-2002.}

Describing the challenge they tried to meet, all tariff review committees used a similar language, - "The balancing of consumers' welfare and the preservation of Bezeq's profitability." Did the committees attain their goals? To measure the committees' success one has to examine the change in the phone rates and the effect they had on Bezeq's profitability.

Throughout the period real phone rates declined by 4 percent annually, summing to a 70 percent decline over the period (Table 5$)^{28}$. The persistent decline of the phone rates could have served as conclusive evidence of the regulator's success, if it had not been for the fact that the rate of price change in the regulatory era (1990-2003) does not differ from that of the pre-regulatory era. The comparison between the periods is, however, misleading. Whereas the rate reduction since 1990 is the result of an active policy applied in a period of low inflation, the price erosion in the previous period was the result of a passive process generated by an erratic macro policy adopted to combat an out-of-control inflation.

Table 5 documents this difference. The period is divided into 4 parts: The low inflation period (1973-1997), the hyperinflation (1977-1985), the first stages of disinflation (1985-1991), and the regulatory period (1991-2003). ${ }^{29}$ The table presents the average annual inflation rate, and the average and the dispersion of the real phone rate changes. It is the standard deviation of the real rate annual changes, much more than the mean, that tells the story of the regulator's price policy.

The steady erosion of the real rates in the first period, accompanied by an increase in the dispersion of the year-to- year changes reflect the government's attempt to slow down

\footnotetext{
${ }^{27}$ To deflect part of the opposition it was ruled that phone lines that are sparsely used are entitled to a discount in the user fees.

${ }^{28}$ The price changes reported in table 5 are the prices of phone services used in the calculation of the Israeli CPI deflated by the change in the average CPI. Since 1997 this index includes also the price of cellular phone prices.

${ }^{29}$ Since the 1990 rate hike by the first overview committee should be considered as a correction of the price erosion in the previous five years, the year 1990 was included in the third period.
} 
inflation by slowing down the adjustment of the prices of government services. The ever increasing deficits made the government realize that this policy was unsustainable. The rate adjustments were speeded up but could not catch up with an inflation process that broke out of control. The result was a slowing down of the real rate erosion and an increase in the dispersion of annual price changes. The nominal price freeze imposed on Bezeq in the first years of its existence continued the real rate erosion, but the erosion was corrected by the rate hike recommended by the first review committee. The regulatory regime ushered in a new era characterized by a steady reduction in nominal (and real) rates with only slight changes from years to year.

A similar story is told by the last column of table 5, which reports the number of annual rate adjustments. In the first period the government stuck to its policy of semi-annual adjustments, even at the cost of rate erosion. The acceleration of inflation forced the government to forsake this policy, and adjust the rates almost monthly. Only when inflation slowed down could the government resume its semi-annual rate adjustment policy, which was replaced in 1992 by one adjustment per year. The suppression of inflation and the new regulatory regime reduced the unintended part of the real rate decline to a minimum.

Since 1997 the CPI "phone service prices" includes also the price of cellular phone prices. To what extent can the decline in "phone service prices" be explained by the decline in the mobile phone rates? The period 1997-2002 is generally regarded as a period of intense competition in the mobile phone services, with the newcomer "Partner" trying to widen its foothold in the market. It could be expected that the aggressive competition would be reflected in a price decline. The CPI mobile price series (Figure 2) comes, therefore, as a surprise. Not only that mobile phone prices did not decline - they rose over the period in real terms by 10 percent (by 40 percent in nominal terms).

There is no argument that the opening of the market to competition, and the entry of Cellcom changed the shape of this market. The decision to make the price of service the decisive criteria in the selection of the first entrant had a revolutionary effect on mobile phone rates. It looks, however, as if the sharp rate decline was a distinct event. After 3 years of competition, prices started to edge upward, competition changing its nature from price to quality-of-service competition. ${ }^{30}$

\footnotetext{
${ }^{30}$ There is also the possibility that "discount packages", so popular in the mobile companies' marketing strategy, are not reflected in the official CPI.
} 
Is the pattern of change of the mobile phone prices unique to that market or is it characteristic of other competitive markets? To answer this question we examined the price behavior of international calls. Figure 3 describes the change of the international call rates since 1990. For the first two years nominal rates did not catch up with the average price increase. In May 1992 rates shot up by more than 60 percent and hardly changed till January $1994^{31}$. At that time Bezeq, expecting the liberalization of the international calls market, lowered the nominal international rates by 30 percent, and froze them voluntarily for the next three years (resulting in their erosion in real terms by another 30 percent) ${ }^{32}$. At the eve of liberalization real rates were, therefore, one half of what they had been four years earlier. The entry of the new rivals forced the incumbent to cut his prices by 70 percent, but this was to be the last rate reduction. Since July 1997 international rates have crept upward at a cumulative rate of 75 percent ( 50 percent in real terms), following the pattern observed earlier in the case of mobile phone services.

Throughout the period both the international providers and the mobile operators enjoyed a sharp decline in the price of their equipment and an excess capacity of international lines. Their customers did not, however, share in this decline of input price. If in the case of the mobile market one can explain price increases as a result of an increase in the quality and diversity of service, this explanation does not apply in the case of international providers.

Not less important than the average decline in phone rates, was the attempt to base the individual rates on costs. The manifestation of this move was a considerable simplification of the rate structure, and the rebalancing of access and traffic tariffs. The monthly user fee in 1989 was equivalent to the cost of 24 minutes of an intercity call at peak hours. In 2003 this ratio rose to 400. Since 1993, when the process of rebalancing started, user-fees increased (in real terms) 2.5 times, while the average price of a phone call was cut by one-half. The income from user fees increased, as a result, in the period 1988-2002 from one-quarter to one-third of Bezeq's phone revenue. This achievement is especially laudable given the traditional bias of the Parliamentary Finance Committee in favor of the residential sector.

\footnotetext{
${ }^{31}$ There is no explanation for the sudden jump in rates in 1992, in particular given the first review committee's recommendation to lower the rates of international calls at a faster rate than the rest of services.

${ }^{32}$ In January 1994 Bezeq, as part of its obligation to lower the average phone rates at the point of entry into the second review period by 10 percent, proposed to lower the international rates by 30 percent and lower the domestic rates by less than 10 percent.
} 
To gain a better appreciation of the Israeli regulator' achievements it is worth comparing the Israeli phone rates with those abroad. Figure 4 describes the users' fees and the average price of a domestic call in Israel and seven West European countries in 1990 and 2000. At the start of the new Israeli regulatory regime Israeli call rates were among the highest in Europe. The price of an average (one minute) call was equal to that in England, and lower only than the prices prevailing in Ireland and Germany. By the end of the decade it was among the lowest (equal to that in Sweden and higher than that in the Netherlands). The lowering of the rates would not have been possible except for the sharp increase in the user fees. Though the Israeli fees are still the lowest in the sample, the difference between the Israeli rate and those of the other countries has shrunk considerably. The Israeli regulator was able to balance the rate to an extent unmatched in the sample, while making Israel at the same time the cheapest country in terms of overall phone rates.

Bezeq's revenue from domestic services in 2002 was 1.18 billion US dollars. If it had not been for the tariff decline, prices would have been higher by 70 percent. An upward estimate of the contribution of the regulatory regime is obtained if one assumes that traffic is insensitive to price. By this estimate, the rate reduction saved in 2002 the Israeli phone customers 0.8 billion dollars. Allowing for a price elasticity of one-half, the estimate of the gains in consumer surplus declines by about one-ninth. ${ }^{33}$

\section{E. The Profitability of Bezeq}

It was shown in the previous section that the rate of decline in Bezeq's tariffs did not differ between the pre-regulatory and the regulatory eras. But whereas in the first period it was the

${ }^{33}$ Let the arc-elasticity of demand be $\eta$. Let the ratio of the price in the absence of regulation $\left(\mathrm{P}_{1}\right)$ to the regulated price $\left(\mathrm{P}_{0}\right)$ be denoted by $\alpha$ [ $\left.\alpha=\mathrm{P}_{1} / \mathrm{P}_{0}\right]$, the ratio of quantities be denoted by $\chi$ $\left[\chi=\mathrm{X}_{1} / \mathrm{X}_{0}\right]$, and let $\mathrm{R}_{0}$ denote the consumers' expenditures following regulation $\mathrm{R}=\mathrm{P}_{0} \mathrm{X}_{0}$. The arcelasticity of demand is defined

$$
\eta=\frac{1-x}{1+x} / \frac{\alpha-1}{\alpha+1}
$$

Hence $\quad \chi=[(1+\alpha)+(1-\alpha) \eta] /[(1+\alpha)-(1-\alpha) \eta]$.

The addition to consumer surplus due to regulation is $C S=(1 / 2)(1+\chi)(\alpha-1) \mathrm{R}_{0}$. Inserting $\chi$ in this equation yields $\quad \mathrm{CS}=\mathrm{R}_{0} *[(\alpha+1)(\alpha-1)] /[(\alpha+1)+(\alpha-1) \eta]$.

The calculation includes both the residential and the business sector, assuming the savings of the latter are transferred to the consumers or increase profits. 
accidental outcome of a process that went out of control, in the second period it was the deliberate result of a process initiated by the regulators. Nowhere is this difference more noticeable than when one examines Bezeq's profitability.

In the years 1973-1984 Bezeq was operated as part of the Ministry of Communication. Since the government accounting system does not report profits, the examination has to be confined to the period since the establishment of Bezeq in 1984 . Throughout the discussion we will distinguish between the period prior to 1997, a period where international calls were still an integral part of Bezeq's operation, and the period since 1997, when the company's activity was confined to the domestic market. To distinguish the range of operation of the company between the two periods we will refer to the company in the second period as Bezeq domestic-operator (D-O). ${ }^{34}$

The profit and loss report of 1984/85 still bears the signs of the destruction the hyperinflation inflicted on Bezeq's profitability. Net profit in that year (15 million dollars, in December 2002 prices) constituted a 1.5 percent return on the company's net worth. Profits revived during the next two years (Figure 5B), but the slowdown of the economy and the price freeze led to a sharp reversal in the years 1988-1989. Given this low base, the rate hike initiated by the first committee tripled the profit. ${ }^{35}$

The fast growth of the early 90s (and especially the growth of the more lucrative services, such as the international calls) led to a fast growth in the company's profits, and by 1993, at the end of the first review period, they were eight times their level in 1988.

The rate cut recommended by the second committee affected profits only for one year, and by 1995 profits bounced back to their original level. However, as Figure 5A indicates, profitability depended crucially on one service - international calls, since income from domestic services did not cover the access deficit. The reliance of profitability on this source of income made the liberalization of the international calls market such an excruciating experience.

Figure 6 shows the fast recovery of Bezeq's profitability from this blow. Bezeq D-O which suffered from substantial losses in the period 1994-1996, was able already in 1997 to balance its books, and enjoyed booming profits from 1998 onward. The average rate of return

\footnotetext{
${ }^{34}$ The third committee reconstructed the account of Bezeq D-O for the period 1994-1996, so one can trace Bezeq's domestic market profits back to 1994.

${ }^{35}$ The recommendations were adopted only in July 1990, so their full effect on Bezeq's profitability is only noticeable in 1991.
} 
from domestic operation in the third review period (1998-2002) was twice the normative rate of 10.5 percent recommended by the committee. The fast recovery is partly explained by the special arrangements made by the regulator on the eve of the opening of that market to competition $^{36}$, but is explained to a large extent by the increased productivity of the domestic operation. Ironically, Bezeq International, the Bezeq's subsidiary that inherited the operation in the international market, was unable to cope with the new competitive environment. Within two years it slid into losses, which took three years to overcome.

Another aspect of Bezeq's financial vigor is presented in Table 6 describing the liquidity stream that the company generated in the last dozen years. As soon as Bezeq got rid of its waiting list it embarked on an ambitious investment program to convert all its switching equipment from analogue to digital switching technology, financing the mass investments through the allocation to depreciation and using the company's burgeoning profits. By 1996, when the program ended, Bezeq discovered that the fast growth of the fixed lines market had come to a halt, and the company found itself with an excess of switching and network capacity. Facing a sharp decline in the cost of equipment (at an annual decline of 10 percent) triggered by world prices and reinforced by the company's increased pressure on its domestic suppliers, the company cut its investment by half. The large allocation to depreciation (which is embedded in the tariffs), and the large profitability, on one hand, and the low investment on the other, generated an unprecedented liquidity stream of over 400 million dollars annually.

Part of this stream was diverted to cover the losses of the Bezeq subsidiaries, but most of it was used to pay back the debts the company incurred in its early years. Not less important were the resources diverted to allow future cost cuts. Since its birth the Bezeq was plagued by excess labor costs. The liquidity stream allowed it to offer its costly employees generous early retirement plans to reduce its inflated wage bill.

It was estimated that the tariff reduction reduced Bezeq's revenue over the period by about 5 billion dollars. The regulator was, however, careful not to undercut the company's financial stability. Bezeq's average annual profits (before taxes) in the pre-regulatory era (1984-1989) were 60 million dollars. Average annual profits grew to 200 million dollars since the initiation of the regulatory regime, and this level was hardly affected by the loss of the company's most lucrative operation- the international calls.

Bezeq's annual profits were on average twice the normative profits. Do these excess profits reflect a failure of the regulatory regime? In some sense, the answer is positive. As

${ }^{36}$ See fn. 8 , 
figures 5 and 6 indicate Bezeq succeeded in showing excess profits even in 1994 and 1999, in spite of the tariff cuts by the review committees. These excess profits can be explained by the committees' conservative approach and by the leniency of the political level when it had to fix the adjustment rates ${ }^{37}$.

The owners of the firm benefited only little from these excess profits. As table 6 indicates, only a small fraction of these profits were distributed as dividends (about one-eight of the after-tax profit). In September 1990 the Bezeq stock was issued for the first time on the Israeli Stock Exchange at a market value of 1.25 billion dollars (in 2002 prices). In May 2005 the government sold its controlling interest in the company at a price of 3.14 billion dollars, reflecting a rate of return of 7.3 percent for the whole period ${ }^{38}$.

Table 6 points out the great winners from Bezeq's profitability. These were the company's employees. One quarter of the profits went to finance the early retirement plans. The excess profits benefited also, though indirectly, the phone service consumers. The profits allowed the reductions in finance and labor expenditures mandated by the tariff cuts. At no point in this process did the rate-cuts look threatening to the company's financial stability, and the generous retirement plans prevented any serious workers' unrest, easing the political acceptance of the committees' recommendations ${ }^{39}$.

\section{F. The Regulator's Impact on Bezeq's Productivity}

The regulator played an instrumental role in the recovery of Bezeq's profitability in the early 90s, and its preservation in spite of the loss of the lucrative international calls market in 1997. It is of interest, however, to explore to what extent the increased profits were attained through an increase in the company's revenues, and how much of the increase is due to a reduction in costs. According to figures 7 and 8 the answer differs between the first and the second half of

\footnotetext{
${ }^{37}$ The committees' conservative approach is reflected in the second review committee's decision to recommend a moderate cut of 10 percent instead of the 16 percent, the rate it thought appropriate. Moreover, all the committees based their estimates of the tariff cut on the company's performance during the previous year, rather than try and forecast its performance in the first year of the new review period, thus ignoring any productivity growth over the two years.

${ }^{38}$ At the height of the stock bubble, in March 2002, the stock of the company hit a value of 4.9 billion, yielding an annual rate of return of 15.6 percent.
} 
the regulatory era. Whereas the recovery of profits in the early 90 s is explained by the fast growth in output and revenue, cost increases lagging behind, the profitability of Bezeq D-O in the second half of the 90s is explained primarily by costs reductions. Increased productivity played, therefore, an important role in explaining Bezeq's booming profits, and the natural question is how much did the regulatory regime contribute to this process?

A simple answer can be found in Bezeq's management and Board of Directors' resolutions calling for increases in efficiency to meet the review committees' tariff cuts. This seemingly simplistic answer is supported by Figures 7 and 8 . Whereas in the pre-regulatory era expenditures outpaced the growth of output, leading to an annual growth of 1.5 percent of the cost per unit of output, cost per unit of output declined at an annual rate of 6.2 percent in the period 1990-1996 and the rate accelerated to 8.4 percent thereafter ${ }^{40}$. The costs decline that was initially confined to capital costs, spread in the second period also to operating costs, including labor costs.

The fast expansion in the late $80 \mathrm{~s}$, and the huge investment it required, were financed primarily through increased credit. It is the increase in capital costs (finance charges and depreciation) that explain the increased cost per unit of output in the pre-regulatory era. The new tariff regime, introduced in 1990, allowed Bezeq to self finance the huge investments required for the conversion to digital equipment, and use its improved profitability to pay back some of its debt in order to reduce its finance charges. Finally, the declining investment in the late 90s and the ample liquidity enjoyed by the company allowed it to get rid of most of its debt, reducing finance charges to a minimum, and trimming down its depreciation allowances.

As impressive as is the decline in capital costs (an annual decline of 10 percent in the period 1997-2002), regulatory pressure contributed only marginally to the process. It led to increased effort exerted by Bezeq's management when bargaining with the company's suppliers, and may explain the conservative investment policy in the late 90s. However, much of this achievement is due to exogenous factors, such as the decline in equipment prices on the world market, that were independent of the regulator's intervention. If one looks for an unambiguous regulatory impact, one has to look at management's effort to cut operation cost.

\footnotetext{
39 The Bezeq workers union initiated several times service interruptions, following the publication of the committees' reports. These interruptions were, however, relatively mild. In recent years the threat of more serious interruptions was curtailed by the high penetration rate of cellular phones.
} 
The slowdown of costs increases from 8 percent in the pre-regulatory era to 4 percent in the early 90s, and the decline of operation costs at an annual rate of 3 percent towards the end of the period bear definitely the imprints of regulatory pressure.

Nowhere is this pressure more discernable than in Bezeq's management effort to wear down the hardcore of inefficiency - labor costs. Wage and salary expenses constitute throughout the period over 60 percent of Bezeq's operation costs. Bezeq's employees, like employees of other government-owned public utility companies, were the prime beneficiaries of their company's monopolistic status. Prior to the establishment of the new regulatory regime Bezeq's employees real wage bill increased at an annual rate of 10 percent. A measure of management's success is the slowdown of the increase in these expenses to 3 percent in the period 1990-1996, and the reduction in the wage bill at an annual rate of 1 percent in the period 1997-2002. Even more impressive is the management's success in cutting down the company's inflated workforce, firing "expensive" employees and replacing them by less expensive ones.

Figure 9 describes the changes in Bezeq's labor force, the wage bill, and the changes in the wage per employee. The first years of Bezeq's independent existence were characterized by a fast growth of its labor force (18 percent in 5 years), a trend that stopped only in 1992 . The shift from analogue to digital switching technology, and increased regulatory pressure led management to embark on a workforce-cuts policy to which it stuck throughout the rest of the period. In its first years the policy affected mainly the temporary labor force, but with time the cuts expanded to incorporate also tenured employees. As a result, Bezeq's labor force in 2001 was 28 percent lower than its level in 1985 and 40 percent lower than the level it attained, at its peak, in 1992. The reduction of the labor force by 4800 employees was clearly an important factor contributing to Bezeq's increased productivity.

These employment cuts did not come without cost. Part of the cost of obtaining the union's consent to these cuts was the generous retirement arrangements for those who left the company. The other part was the generous wage contract enjoyed by those who stayed. The union's cooperation was won at a price of a continuous increase in the average wage per employee. In the period 1995-2001 the average real wage of Bezeq employees doubled, compared with an increase of 70 percent in the wage of public employees, and an increase of 50 percent for the economy as a whole. Since the change in the average wage per worker was

\footnotetext{
${ }^{40}$ The growth in output is measured as a weighted average of the growth in lines and the growth in traffic, the weights being 0.6 and 0.4 , respectively.
} 
accompanied by a change in Bezeq's labor force composition - the retirement of older "expensive" employees and the entrance of young "cheaper" employees, the 100 percent wage gain understates the true increase in real wages. This increase in wages offsets a large part of the effect of the labor force decline. In the period 1992-2001, the company's workforce was cut by 40 percent, but its wage expenses went down only by 9 percent.

If the average wage at Bezeq would have grown at a rate identical to the national average, the company would have saved over these years the sum of almost 0.8 billion dollars (in 2002 prices). In 1982 the government agreed to award the workers substantial wage increases in order to gain the union's approval for their change in status from government employees to employees of an independent company. Our estimate of 0.8 billion understates, therefore, the rent the employees received in the form of inflated wage If we add to this amount the 0.6 billion they received in the form of increased retirement benefits, the workers are clearly the main beneficiaries of the company's monopolistic status. Bezeq is another example of an inherent paradox in the operation of a government monopoly - it has to pay in terms of increased wages for any increase in productivity!

To what extent did Bezeq's actual costs follow to the trajectory of normative ("allowed") costs prescribed by the review committees? The comparison in figure 10 of actual and normative costs shows a different pattern of behavior in the first two review periods (1990-1993, 1994-1998) and the third one (1999-2002). In the first two periods the company's costs followed the norm for the first two years of each review period, but exceeded the norm as the end of the review period approached. The review committees suspected that the divergence was not accidental, but rather part of a calculated policy aimed to set a higher benchmark for tariffs in the following period. Consequently, the committees ignored the increased costs, forcing Bezeq to slash its costs in order to maintain its profit targets. It seems that the lesson has been learned, and almost throughout the third review period actual costs fell short of the normative ones. The improved fit of actual and the normative costs can be given two interpretations: the first interpretation attributes the better fit to the committee's improved forecast of the company's efficiency potential. The second interpretation regards the "normative costs" as a disciplinary device. According to this interpretation, the setting of norms played an important role in restraining the increase in the monopoly's expenditures in the early 90s and in their reduction at the end of that decade. 


\section{G. Theory and Reality - Some Lessons based on the Israeli Experience}

Neoclassical economic theory emphasized the disruptive effect of monopolies on the allocation of resources and the distribution of welfare between consumers and the owners of the monopolistic firm. The new regulation literature added to the monopoly evils the sin of inefficiency, but the emphasis was shifted from the discussion of the problems of monopolies to the problems of regulating these monopolies. If the early literature focused on the monopoly's reaction to the regulatory rules (for example, the Averch-Johnson effect) the new literature analyzes the regulator's behavior, given his objective function and the constraints he faces. Though economists agree that the regulator is attempting to maximize his own welfare, there is disagreement on how the regulator's welfare is related to the welfare of the agents affected by his decisions (consumers and firms), and how he attains his aims. At one extreme, the regulator is depicted as captured by the firms, and at the other extreme the regulator is assumed to identify fully with the consumers, adopting an opportunistic policy that sacrifices profits for lower prices (Newbery, 1999). A major constraint affecting the regulator, according to this literature, is the scarcity of information, and specifically the asymmetry in information between the firm and its regulator. Not less important, but perhaps even less tangible, are institutional constraints (Levy and Spiller, 1994), and specifically, the regulator's independence (Edwards and Waverman, 2006).

The new economics of regulation literature reflects, to a large extent, the U.S. experience, and gained impetus with the increasing popularity of privatization. It is worthwhile to explore the extent to which these observations apply to the pre-privatization era. After all private ownership of public utilities was quite rare in most economies till the mid ' $90 \mathrm{~s}^{41}$, and the regulators' formative years were, most probably, spent confronting a publicly-owned monopoly. At first sight our story does not fit this model, since in Israel throughout the two decades covered by our discussion a publicly owned monopolist faced a government controlled regulator. But in second thought there is a lot to be learned from the Israeli experience on the behavior of the regulated firm in the pre-privatization era, and some of the lessons derived from the Israeli regulator's behavior seem to apply to the regulatory process in general.

\footnotetext{
${ }^{41}$ The only public utility industry in Israel that was not dominated at the time by a government owned monopoly was public transport which was dominated by two large cooperatives.
} 
The profit motive played only a secondary role in the Israeli government's objective function guiding the operation of the public utility industries. Employment has always preceded profit in the government's list of priorities. During the late '70s and early '80s the top place on the list was shared by macro considerations: what effect will tariff changes have on the rate of inflation. This attitude did not change much when Bezeq became an independent entity. The low role of profits in the owner's list of priorities is reflected in the minor role played by the Government Companies Authority in both the liberalization and the regulation of the public utility industries ${ }^{42}$. The vacancy left by the owners was filled by the workers' union. They regarded the company's profitability as essential to the preservation of their generous wage arrangements, and they were in the forefront of the fight against any attempt to curtail the companies' profitability either through liberalization or through regulation ${ }^{43}$. The "workers' capture" of the monopoly had far reaching implications for the regulator's objective function, the constraints he faces and the aims of regulation.

The model of "regulatory capture", formulated by Stigler (1971) and Peltzman (1976), foresees regulated firms offering former regulators lucrative appointments. Applying this model to the Israeli experience one has to distinguish between the professional level in the regulating bodies and the political level. As long as the public utility companies were government owned, and, hence, subject to the public employees' pay-scales the tendency of members of the professional level to move to the regulated firms was relatively rare. Ironically, it has become much more prevalent once the industries have been opened to competition, and these workers could use their specific skills in the private sector working for the new entrants ${ }^{44}$. The political level, on the other end, has shown little capacity to accumulate the specialist's knowledge that regulated firms may find worth paying for ${ }^{45}$. In

42 The Government Companies Authority is part of the Ministry of Finance. However, the unit responsible for the liberalization and regulation of the public utility industries in the Ministry was the Bureau of the Budget. The Government Companies Authority has turned into a major player in the public utility industries only in the late '90s when the government embarked on its privatization drive.

43 The pattern characteristic of Bezeq's workers' union applies also to those in the Israeli Electric Company, the ports, the Israeli Refineries, fuel pipelines and storage companies, and the water company.

44 The incentive of obtaining a leading job with one of the new entrants must have affected also Bezeq's management. Success in running Bezeq, one of the largest companies in the country, can serve as a signal to one's managerial skills.

45 The frequent turnover of ministers among the different ministries reduces their capacity to accumulate the specialized skills required in any specific industry. The only exceptions are lawyers 
their case the reward is, therefore, not pecuniary but has to be measured in terms of political power. In the Israeli political arena workers' unions carry a much greater weight with the two large parties than with the smaller ones. It is noteworthy that the liberalization of the telecommunication market was led by two ministers who represented small parties that were not subject to the workers' union pressure ${ }^{46}$. When it came to rate setting, union pressure on the political level turned out to be ineffective where the rate cuts at the beginning of the review periods were concerned, but resulted in the reduction of the adjustment rates $(\mathrm{X})$ proposed by the committees ${ }^{47}$. Newbery (1999), worried of the regulator's exploitative behavior, draws a picture of "a mass of local voting consumers" facing a politically defenseless owner. Nothing can be further away from the reality of the Israeli political arena, where an unorganized consumer public faced a well organized workers' union forcefully defending the rents they derived through Bezeq's monopolistic status. Newbery observes that "under public ownership, interest groups will compete in the political market place for benefits, while under private ownership, the regulator will represent the interests of the nonowning groups". The Israeli experience clearly supports the first observation, but indicates that the representation of the consumer public by the regulator is not, necessarily, confined to the case where the monopoly is privately owned.

The small weight given to profit maximization in the owner's objective function made increased productive efficiency the prime target of the regulator. Allocative efficiency played only a secondary role in the regulator's priorities in the early phases of the new regulatory era. True that the resources allocated to communication services till the mid ' 80 s were too small from an economic perspective, but this misallocation was not motivated by profit maximization, but rather by general government inefficiency.

The increased emphasis on productive efficiency would have called for performancebased ratemaking. Laffont and Tirole $(1993,2000$, p.39) phrased the term "the power of the incentive scheme". In their formulation, $p=\bar{p}+(1-\rho) c$, where $\rho$ denotes the power of the

serving in the legislative or the executive branches who can take advantage of the knowledge they have accumulated on the regulatory process itself.

46 For many years the Ministry of Communication ranked as a ministry of secondary importance, increasing the probability that it will be headed by a minister from a small party. Periods when the ministry was headed by a representative of one of the large parties were in general characterized by lack of reform.

47 The parliamentary hearing of the last cut in Bezeq's tariffs in 2003 was attended by more members of the union's secretariat than members of the regulatory ministries. The parliamentary committee decided to reduce the adjustment rate from 3.5 (the rate approved by the Ministers) to 2.5 percent. 
incentive scheme $(0 \leq \rho \leq 1)$, and $c$ denotes cost. In a high powered incentive scheme the price is insensitive to changes in $\operatorname{costs} p=\bar{p}$, while in a low powered incentive scheme (i.e., perfect passthrough price setting) $p=c$, and a change in cost hardly affects the firm's profit. A major constraint in the choice of $\rho$ is, as Laffont and Tirole emphasize, the regulator's stock of information.

The Israeli example demonstrates the Laffont and Tirole argument. The high priority given by the regulator to productive efficiency would have called from the start to chose a tariff setting menu where $\rho=1$. In effect we observed that the first review committee adopt a passthrough policy, adopting Bezeq's realized costs as the normative cost base. The rationale for this choice was the regulator's attempt to dispel the company's fear of exploitation, and the lack of information. The same reasons explain the low adjustment rates (X) applied in the first review period. The accumulation of information allowed the second review committee to choose a price setting recipe where "controllable" costs are assigned a fixed price but "uncontrollable" costs are adopted as is. Finally, the third and fourth review committees set a fixed price formula based on normative costs. The more ambitious adjustment rates (X) adopted by the second review committee and it successors can also be traced to the increased accumulation of knowledge by the regulator.

However, the Israeli experience demonstrates also a point that is sometimes forgotten. The completeness of information and the asymmetry in information between the regulator and the firm are not exogenous. The investment in information is endogenous, and depends on the cost and returns of the investment. The returns to information increase with competitive pressure and with the power of the regulatory scheme. A company used for decades to a rate setting based on 'cost-plus' had little use for a costly information system, and spent on its accounting system only the minimum required by its creditors and the Securities Exchange Authority. It was the increased emphasis on productive efficiency, and the increased competition from the mobile companies that made Bezeq realize the importance of a more sophisticated information system. ${ }^{48}$

Paradoxically, the asymmetry between the regulator and the firm may have increased over time. At the starting point there was a full symmetry between Bezeq and its regulators the accumulated knowledge on demand and cost conditions of both parties was scant. Moreover, as long as Bezeq was a monopoly providing domestic, international and mobile phone services, it did not make any effort to conceal its information. Its statistical abstract

\footnotetext{
${ }^{48}$ It is worth remembering that it was the regulator who initiated Bezeq's first costing system
} 
was easily accessible and contained a wide variety of information on the company's technical and financial activity. Bezeq's attitude changed once its market opened to competition and the information was regarded a commercial secret ${ }^{49}$.

Why in the absence of local information did the regulator not rely on benchmarking? Armstrong, Cowan and Vickers (1994, ch.3) argue that the attractiveness of yardstick competition increases with the correlation between the cost of the regulated company and the cost of the companies for which the information exists. The correlation may be low when the industry is in the midst of fast technological changes. Differences in the vintage of the technology (for example the shift from analogue to digital switching equipment or from copper to fiber optic network) will create significant differences in costs ${ }^{50}$. Not less important are differences in the cost of labor which depend crucially on the relative power of unions in the various companies. Finally, the cost comparison may reflect not differences in technology or input prices, but rather the success of regulators to curtail costs. Consequently, the Israeli review committees preferred to rely on the local experience rather than employ international comparisons.

The first review committee called its recommended rate setting method "price-cap". In effect, the proposed procedure never satisfied the definition, since, officially, the regulated firm was never given the discretion to set the tariffs for its various services (subject to an average rate restriction). The first committee set this restriction because it felt that Bezeq lacked the information required for this exercise. The reluctance of the following committees to transfer the power of detailed rate-setting to the company is explained by their fear that Bezeq, given the oncoming opening of the markets (the international and later the domestic) to competition, will take advantage of this power to set anti-competitive prices ${ }^{51}$. It took, however, almost a decade before the regulator himself acquired sufficient information (and self confidence) to propose a radical overhaul of the tariff structure.

\footnotetext{
${ }^{49}$ Bezeq stopped publishing its statistical abstract in 1997. A similar phenomena of concealment of information is reported by Taylor (1994,ch.11) for the US long distance market.

${ }^{50}$ Bezeq was fortunate in being a relatively latecomer to the field. As a result it had only relatively small resources invested in the old technology, allowing it to adopt the more efficient equipment faster. .

${ }^{51}$ Bezeq's policy of cutting international rates prior to the liberalization of the international market (p.19) and some of the rate programs to bulk customers proposed by Bezeq in the late '90s offering a discount-scale that increases over time (resulting in increased cost of separation to the customer) were definitely meant as a threat to any new entrant into these markets.
} 
Allocating common costs the committee followed other Western regulatory authorities in rejecting Ramsey pricing in favor of an amended proportional markup formula. The committee's main concern was the distributive effect of the Ramsey pricing method, and specifically, the sharp increase in the access tariffs it implied. At the same time it was also aware of the difficulty in convincing the consumer public of the benefits of a "single till" approach (Laffont and Tirole, 2000, pp 73-80). The committee was ever-conscious of its advisory status, and felt that a recommendation involving a sharp rise in the monthly user-fee might undermine its credibility with the parliamentary Finance Committee, and jeopardize the whole recommendation package. It settled, therefore, for modest increases in the monthly user fee, though it meant that phone traffic had to be charged an inflated markup (of over 200 percent) to cover the common costs.

The committee's dilemma is best explained by table 7. The table describes Bezeq's revenue from access and traffic for the year 1998, the committee's estimate of the direct costs of these services, and the company's output, where access is measured by the number of lines (in thousands) and traffic is measured as a weighted number of minutes (in millions). Common costs allocated to telephony constituted over one-half of the direct costs (almost 300 million dollar). The problem of the allocation of common costs was aggravated by the imbalance between access and traffic in revenue and costs. Whereas access constituted only one-third of revenue, it constituted almost 70 percent of direct costs. According to the committee's estimates, the 1998 annual user fees of $\$ 126$ fell short of the average direct access costs (\$136). Assuming that the demand elasticities for access and traffic are -0.1 and -0.5 , respectively, and ignoring (for simplicity) the cross-elasticity, a proportionate markup of 45 percent to cover the common costs, would have required an increase in the user fees by 57 percent, and allowed a cut of 66 percent in traffic tariffs (a cut from 2.3 cents per minute to 0.8 cents). ${ }^{52}$ Ramsey pricing would have required a user-fee hike of almost 90 percent and the lowering of traffic tariffs by three-quarters.

Bezeq's 1998 revenue exceeded normative costs (direct plus common costs) by more than a quarter. Consequently, both rate programs involve a substantial cut in the "average" rate, and a significant increase in the consumer surplus. The difference between the two

\footnotetext{
${ }^{52}$ Hausman, Tardiff and Belinfante (1993) show that allowing for the cross-elasticities between access and intercity tariffs mitigates considerably the welfare loss associated with the increase in the access charges. Allowing for these elasticities, given their low estimates, does not change the results of our exercise.
} 
methods in the consumer surplus generated by the rate changes is, however, surprisingly small - only 2 percent ${ }^{53}$.

The committee, worried that such sharp increases in user-fees would be unacceptable to the Finance Committee, shied away from both recommendations. The user fee was set equal to the average direct cost of access (\$136) and the common costs were fully assigned to traffic. The calculation shows, that in spite of the imperfect pricing formula, the difference between the consumer surplus generated by this method and by Ramsey pricing is only oneeighth $^{54}$.

The results in table 7 are not accidental. Formally, assuming the firm produces two independent services subject to a zero profit constraint

$$
\mathrm{m}_{1} \mathrm{R}_{1}+\mathrm{m}_{2} \mathrm{R}_{2}=\mathrm{A}
$$

where $m_{i}$ denotes the markup rate $\left[m_{i}=\left(p_{i}-c_{i}\right) / p_{i}\right], R_{i}$ denotes the expenditures on service $i$, and $\mathrm{A}$ denotes the common costs. Differentiating, and assuming marginal costs are constant, one obtains the compensating price changes under price-cap

$$
\mathrm{d} l n \mathrm{p}_{2} / \mathrm{d} l n \mathrm{p}_{1}=-\mathrm{R}_{1}\left(1-\mathrm{m}_{1} \eta_{1}\right) / \mathrm{R}_{2}\left(1-\mathrm{m}_{2} \eta_{2}\right)
$$

The resulting change in consumer surplus equals

$$
\mathrm{d} C S=-\left(\mathrm{R}_{1} \mathrm{~d} \ln \mathrm{p}_{1}+\mathrm{R}_{2} \mathrm{~d} \ln \mathrm{p}_{2}\right),
$$

which given the price-cap constraint equals

$$
\mathrm{d} C S=\left\{\left[\left(1-\mathrm{m}_{1} \eta_{1}\right) /\left(1-\mathrm{m}_{2} \eta_{2}\right)\right]-1\right\} \mathrm{R}_{1} \mathrm{~d} l n \mathrm{p}_{1} .
$$

Hence the price of service 1 should be raised as long as $m_{1} \eta_{1}<m_{2} \eta_{2}$, which is the Ramsey formula. However, the formula also indicates that the increase in consumer surplus is diminishing with the change in prices, so fine-tuning may not be worth the effort. Specifically, if there exists a bias towards the welfare of the consumers of the service with the lower price elasticity (say, access), then the change in social welfare equals

$$
\mathrm{d} C S=-\left(\rho \mathrm{R}_{1} \mathrm{~d} \ln \mathrm{p}_{1}+\mathrm{R}_{2} \mathrm{~d} \ln \mathrm{p}_{2}\right),
$$

where $\rho>1$ denotes the bias coefficient. In this case rebalancing should proceed only as long as $\left[\left(1-m_{1} \eta_{1}\right) /\left(1-m_{2} \eta_{2}\right)\right]>\rho$. Given the data in table 8 even a relatively small bias in favor of the consumers of access $(\rho=1.15)$ would have made a proportionate markup socially

\footnotetext{
53 When elasticities are constant the change in consumer surplus equals $\Delta R /(1+\eta)$, where $\Delta R$ denotes the change in expenditures (i.e., revenue) and $\eta$ is the demand elasticity of the specific service.

${ }^{54}$ The figures in table 8 differ somewhat from the committee's final recommendations, mainly because the latter were based on the assumption of completely inelastic demand curves. Our calculations yield very similar results of the change in consumer surplus when we assume that the price elasticities of access and traffic are 0.05 and 0.75 , respectively, or when we use the 2002 data.
} 
desirable. In general, the bias coefficient that will make a proportionate markup $\left(\mathrm{m}_{1}=\mathrm{m}_{2}=\mathrm{m}\right)$ socially optimal satisfies

$$
\rho-1=\left(\eta_{2}-\eta_{1}\right) /\left[(1 / m)-\eta_{2}\right]
$$

The coefficient will not differ substantially from one as long as the markup (m) is sufficiently small and the difference in elasticities is not too large.

There was another reason why the committee did not consider Ramsey pricing namely the asymmetry in resources between the regulator and the regulated company. The regulatory process is costly to both the regulator and the company. But whereas the first acts within a well restricted budget, the company is bound only by the profit constraint. It will be ready to invest in additional information, or consulting services, as the long as the expected returns exceed the marginal cost. If a consultant (or a lobbyist) could have promised Bezeq that the rate cut would be reduced by 1 percentage point, his effort would be worth to the company 10 million dollars. To offset this imbalance the committees tried to keep their recommendations as simple and transparent as possible. Ramsey pricing does not satisfy this criterion.

The estimation of demand elasticities for telecommunication services has become a common procedure in the US regulatory regime. It is less common in Europe, and has never been undertaken in Israel. The committees felt that moving into this untapped territory would have entangled them in lengthy controversies on secondary issues. The committees feared that Bezeq would try to utilize the elasticity estimates to lower tariffs of services where it has competitive disadvantage, and raise the tariffs of services where its monopolistic status was secure. Bezeq's proposal to introduce a countrywide uniform rate for all phone calls showed that the fear was not imaginary. The proposal was intended to increase the price differential between Bezeq and its mobile phone competitors in the inter-city segment of the market (where its cost margin was quite slim) at the expense of the tariff of local calls, where the company did not fear competition. A similar concern led the committees to calculate the rate cuts assuming zero demand elasticities and basing the calculation on current output, though they were aware that in a growing market this calculation method will not eliminate excess profits $^{55}$.

The issue of the proper markup formula became in particular bothersome when the third review committee set, for the first time, the interconnect rates. The committee faced a

\footnotetext{
${ }^{55}$ For a discussion of the proper weighting scheme of output see Armstrong, Cowan, Vickers (1994) and Sappington (2002).
} 
mixture of rates set mostly by the Minister of Communication and reflecting the relative power of Bezeq and the interconnecting company (cellular phone or international calls). On the basis of its estimate of the direct cost of a regular call the committee had no difficulty calculating the cost of an interconnect call, but had a difficult time deciding how to assign the common cost. It rejected ECPR, which would have meant assigning a 200 percent markup, the same markup assigned to regular calls. It also felt uneasy with the single-till assumption underlying Ramsey pricing. The solution adopted was a compromise: since a regular call involves two Bezeq switches, and an interconnect call only one, the markup was set at a rate which is only one half that of a regular call. It is worth noting that though the argumentation may be unacceptable to Ramsey pricing disciples, the result is in line with Ramsey principles given the greater price elasticity of mobile and international calls. ${ }^{56}$ Edwards and Waverman (2006) hypothesized that the smaller is the regulator's independence the more he will favor the publicly owned incumbent when setting interconnect rates. The Israeli observations are clearly not consistent with this hypothesis- the interconnect rates established by the committee being among the lowest in Europe. ${ }^{57}$

Institutional constraints may explain also another deviation of the Israeli rate-setting formula from its UK model. According to the price-cap method the price trajectory is determined solely by one parameter- the adjustment factor X. The Israeli ad-hoc review committees adopted a two-stage system, consisting of a discrete change at the beginning of each review period, and a gradual change (determined by $\mathrm{X}$ ) during the review period. The discrete change was based on the committees' calculations of the monopoly's "excesses" (i.e., the excess profit and excess costs) in the previous period, while the adjustment factor $\mathrm{X}$ was based on their evaluation of future cost savings (due to increases in output, returns to scale, a decline in the price of equipment, and cut downs of superfluous labor). The first committee chose the two-stage formula because it recommended an initial rate hike. The following committees did not change it when they discovered that it was much easier to convince the politically oriented decision makers of the validity of their estimates of Bezeq's past performance than of its future efficiency potential.

\footnotetext{
56 A lower markup on interconnect than regular calls would have also been recommended by proponents of Armstrong's "replacement ratio" approach (Armstrong, 2002, p.311)

${ }^{57}$ Under the price-cap rules, setting lower interconnect rates would not have affected the monopoly's profitability, since it would have called for higher local call rates.
} 
Newbery raises the fear of the exploitative nature of regulation -a regulator ready to sacrifice profits for lower prices, thus undermining the company's capacity to renew its equipment. Some may cite the low normative rates of return $(8.5$ percent for the first eight years of the regulatory regime and 10.5 and 13 percent later on) as supporting this view. The committees, however, familiar with Bezeq's performance knew that the normative rate was just a "floor" for the company's profitability, and should the company face a major unexpected threat to its profitability- the regulator will intervene. The reduction of the X-factor, to compensate the monopoly for the opening of the international market to competition, proved the committees correct ${ }^{58}$. Given Bezeq's profits record it seems natural to blame the regulator for excess leniency. Afraid that the erosion of the company's profitability may affect their own credibility, the committees were not severe enough in their recommendations of rate cuts.

Finally, in their evaluation of the Price-cap system several researchers (Laffont-Tirole, 2000 ch.2; Sappington, 2002) voiced the fear that a rigorous control of prices may affect service quality. In the case of the Israeli telecommunication industry this fear has not materialized. The switch from analogue to digital technology in the early '90s, and the competition with the cellular phone (and the threat of entry) assured the Israeli consumer of a constant improvement both in the scope and the quality of service.

\section{H. Summary and Conclusions}

Bezeq has come a long way since it became an independent company two decades ago. Its road was shaped by technological change and structural reforms, but not less important was the interaction between the company and its regulators.

Since the establishment of the new regulatory regime in 1990 real phone rates declined at an annual rate of 4 percent. Even more impressive, the decline of the regulated domestic fixed line rates outpaced, in the last nine years, those of the competitive industries the mobile phone and the international calls.

Since 1994 the rate decline has been accompanied by a complete overhaul of the rate structure to reflect the services' costs. The main achievement of this restructuring effort was the rebalancing of access and traffic rates. In 1994, when the process started, the ratio of the monthly fee and the rate per minute was 24, in 2003 this ratio increased to 400 . The sharp cuts

\footnotetext{
${ }^{58}$ Sappington (2002) calls this type of correction the Z-factor.
} 
in cross- subsidization laid the groundwork for the opening of the domestic communication market to competition.

Regulation is in general associated with a decline in the regulated company's profit. The Israeli regulator succeeded in balancing consumers' welfare and the company's financial stability. The company's annual profit, which averaged 60 mullion US dollars prior to the initiation of the new regulatory regime, grew to an average of 200 millions afterwards. This achievement is in particular noteworthy given the spin-off of Bezeq major profit center - the international calls market. The company was privatized in May 2005. The annual rate of return on the company's stock, since it was originally issued in 1990, was 7.3 percent.

The excess profitability enjoyed by Bezeq allowed it to face the strict efficiency requirements imposed by the regulator. The company was able to cut its cost per unit, at first because of the fast growth in output and later by cutting absolute costs. The cost cuts were achieved through reduction in the company's finance costs, and, more important, by cuts of its inflated labor costs. To attain the cuts in its labor force the company had to raise the wage of those remaining. The great beneficiaries of the large profits were, therefore, the company's employees, whose share in the rent, in the form of inflated wages and generous severancepay arrangements, exceeded 0.8 billion US dollars.

The theoretical literature emphasizes the asymmetry in information between the firm and its regulator which forces the regulator to compromise on his allocative and distribution goals. The Israeli experience demonstrates some of the shortcomings of the static analysis. The stock of knowledge is not constant. To judge by the Israeli experience, the regulative process can serve as a stimulus for the accumulation of information, and the rate of accumulation is no less important than the asymmetry between the regulator and the regulated firm. Similarly, the literature ignores the asymmetry in means (financial and legal) between the two sides in this legal scramble. His inferiority will force the regulator to adopt a simple and transparent policy, even if a more complex policy (for example, Ramsey pricing) would have led to gains in efficiency.

The regulator's achievements are in particular noteworthy given the institutional constraints. The Israeli regulator has never gained the degree of independence enjoyed by his European and American counterparts. A major part in the rate setting process was played by ad-hoc review committees, but the committees were granted only an advisory role, the final decision resting with politically oriented decision makers (the Ministers of Finance and Communication and the Parliamentary Finance Committee). The ad-hoc committees, aware of 
the parliament members' distributive concerns, mitigated their recommendation concerning the pace of rebalancing.

The competition in the domestic communication market was slow in coming. A natural question is how good a substitute was regulation for competition? There is no simple answer to this question. The experience of competition in the European fixed lines markets is too brief to lead to lead to any clear-cut conclusions. If we were to judge on the basis of the rate of decline of the Israeli and European phone rates- the Israeli regulator did a very good job. Furthermore, even in Europe the decline cannot be attributed fully to the forces of competition, and the regulators played an important role in accelerating the process (Newbery, 2000 pp. 322-328).

The comparison of the price changes in the regulated domestic market and those in the competitive mobile phone and international calls markets is illuminating. The price levels in both markets prior to liberalization were artificially high relative to the industries' cost structure. In both markets the newcomers were chosen in an open bid were the determining criterion was the price of service. The winners offered to slash existing prices by tens of percents, and the incumbent had to adjust to this new competitive environment immediately. It is doubtful whether any regulator could have attained the results attained by the anonymous forces of competition.

On the other hand, one should not ignore the continuity of the regulatory process. The decline in the domestic phone rates continued persistently throughout the last 15 years. The price setting in the competitive market can be broken into two stages: the "penetration" stage of the new competitors into the new market is characterized, as we have noted, by a sharp rate cut. However, once the market split in the new market stabilizes the rate decline is replaced by a slow but steady crawl of rates upward.

Newbery (1999, p.127) summarizes the lessons to be drawn from the first decade of privatization:" The main lesson to draw is that the quality of regulation is a key determinant of performance whether the utility is public or private... Compared to the quality of regulation, ownership seems relatively less important, though there may be more chance of high-quality regulation under private than public ownership". Agreeing with the first part of this observation, I have my reservations with respect to the second part. The government often plays the role of an absentee landlord. A"high-quality" regulator can be more effective in this regime than when he has to face the united front of a private owner and the employee union.

The regulatory regime allowed the incumbent to phase in gradually into the new competitive environment. When the domestic market finally opened to competition in 2005, 
liberalization hardly affected prices. The European experience shows that liberalization often led to gains in welfare of the business sector at the expense of the residential sector. Hopefully, the increased productivity of Bezeq and rebalancing should mitigate the blow to the Israeli residential sector. 


\section{References:}

Armstrong M. (2002), "The Theory of Access Pricing and Interconnection”, in Cave M.E., Majumdar S.K. and Vogelsang I. Handbook of Telecommunication Economics, Elsevier.

Armstrong M., Cowan S. and Vickers J.(1994), Regulatory Reform: Economic Analysis and British Experience, MIT Press.

Edwards G. and Waverman L. (2006), "The Effect of Public Ownership and Regulatory Independence on Regulatory Outcomes", Journal of Regulatory Economics, 29 (1): 23-67.

Gandel N. (1999), "Deregulation and Reform in the Israeli Domestic Telecommunication Market", The Economic Quarterly, 46:3 (in Hebrew)

Gronau R. (2002), "Structural Changes in the Public Utilities Sector in Israel - The Reform that Never Was", in A. Ben-Bassat (ed.), The Israeli Economy, 1985-1998: From Government Intervention to Market Economics, MIT Press.

---------- (2006), “The Regulation of the Israeli Telecommunication Industry An Interim Report", The Economic Quarterly, 53:1 (in Hebrew).

Hausman J., Tardiff T. and Belinfante A. (1993), “The Effects of the Breakup of AT\&T on Telephone Penetration in the United States", The American Economic Review, 83:2, 178-184.

Laffont J.J. and Tirole J. (1993), A Theory of Incentives in Procurement and Regulation, MIT Press. (2000), Competition in Telecommunication, MIT Press.

Levi-Faur D. (1999). “The Dynamics of Liberalization of Israeli Telecomunication: Policy Emulation and Policy Innovations Outside the Joint-decision Trap", E. Kjell and D. Marit (eds) Telecommunications Liberalization in Europe, Routledge, pp.173-190.

Levy B., and Spiller P.T. (1994), "The Institutional Foundation of Regulatory Commitment: A Comparative Analysis of Telecommunications Regulation", Journal of Law , Economics and Organization, 10 (2):201-246.

Newbery D. M. (1999), Privatization, Restructuring, and Regulation of Network Utilities, MIT Press. 
Peltzmzn S. (1976). "Towards a More General Theory of Regulation", Journal of Law and Economics, 19 (2): 211-240.

Sappington D. M.(2002), “ Price Regulation”, in Cave M.E. et al. Handbook of Telecommunication Economics, Elsevier.

Spiller P.T. and Vogelsang I. (1996), "The United Kingdom: A Pacesetter in Regulatory Incentives", in Levy B., and Spiller P.T.(eds) Regulation, Institutions, and Commitment - Comparative Studies in Telecommunication Cambridge: Cambridge University Press.

Stigler G. J (1971), ”The Theory of Economic Regulation”, Bell Journal of Economic and Management Science 2:3-21.

Taylor L. D.(1994), Telecommunication Demand in Theory and Practice, Kluver. (2002), “Customer Demand Analysis", in Cave M.E. et al. Handbook of Telecommunication Economics, Elsevier. 
Table 1. Access and Traffic - Bezeq 1984-1996

\begin{tabular}{lcccc}
\hline & \multicolumn{2}{c}{ Phone lines } & \multicolumn{2}{c}{ Minutes } \\
\hline & Thousands & Index & Millions & Index \\
\hline $\mathbf{1 9 8 4 / 8 5}$ & 1103 & 100 & 5803 & 100 \\
$\mathbf{1 9 8 5 / 8 6}$ & 1208 & 110 & 6192 & 107 \\
$\mathbf{1 9 8 6 / 8 7}$ & 1313 & 119 & 6985 & 120 \\
& & & & \\
$\mathbf{1 9 8 6}$ & 1283 & 116 & 6681 & 115 \\
$\mathbf{1 9 8 7}$ & 1392 & 126 & 8150 & 140 \\
$\mathbf{1 9 8 8}$ & 1472 & 133 & 8750 & 151 \\
$\mathbf{1 9 8 9}$ & 1534 & 139 & 9700 & 167 \\
$\mathbf{1 9 9 0}$ & 1626 & 147 & 10400 & 179 \\
$\mathbf{1 9 9 1}$ & 1704 & 154 & 11200 & 193 \\
$\mathbf{1 9 9 2}$ & 1804 & 164 & 12361 & 213 \\
$\mathbf{1 9 9 3}$ & 1958 & 178 & 14597 & 252 \\
$\mathbf{1 9 9 4}$ & 2138 & 194 & 16100 & 277 \\
$\mathbf{1 9 9 5}$ & 2343 & 212 & 18072 & 311 \\
$\mathbf{1 9 9 6}$ & 2539 & 230 & 18758 & 323 \\
& & & & \\
\hline Annual Growth rate (\%) & & & & \\
$\mathbf{1 9 8 4 - 1 9 9 0}$ & & $\mathbf{7 . 0 \%}$ & & $\mathbf{1 0 . 7 \%}$ \\
$\mathbf{1 9 9 0 - 1 9 9 6}$ & & $\mathbf{7 . 7 \%}$ & &
\end{tabular}

Source: Bezeq Annual Statistic Reports 1987-1996 
Table 2. Bezeq Traffic 1995-2002

\begin{tabular}{|c|c|c|c|c|c|c|c|c|}
\hline & 1995 & 1996 & 1997 & 1998 & 1999 & 2000 & 2001 & 2002 \\
\hline \multicolumn{9}{|l|}{ Subscribers } \\
\hline (thousands) & 2,343 & 2,545 & 2,675 & 2,807 & 2,878 & 3,021 & 3,033 & 3,023 \\
\hline \multicolumn{9}{|l|}{ Traffic (mil. Minutes) } \\
\hline Local & 14,225 & 14,705 & 13,347 & 13,462 & 13,259 & 13,020 & 12,170 & \\
\hline Intercity & 3,847 & 4,054 & 5,441 & 5,488 & 5,405 & 5,307 & 4,961 & \\
\hline \multicolumn{9}{|l|}{ Total land to land } \\
\hline Internet & - & - & 1,064 & 1,976 & 3,602 & 8,261 & 14,217 & 13,984 \\
\hline Land to mobile (LTM ) & 628 & 1,314 & 1,839 & 2,163 & 2,656 & 3,341 & 3,692 & 3,555 \\
\hline Mobile to land (MTL) & 688 & 1,384 & 1,880 & 2,074 & 2,457 & 2,747 & 2,911 & 2,836 \\
\hline \multicolumn{9}{|l|}{ International } \\
\hline interconnect & 669 & 778 & 876 & 1,090 & 1,287 & 1,393 & 1,489 & 1,541 \\
\hline Total & 20,057 & 22,235 & 24,447 & 26,253 & 28,666 & 34,069 & 39,440 & 38,023 \\
\hline \multicolumn{9}{|l|}{$\underline{\text { Index }(1998=100)}$} \\
\hline Subscribers & 83.5 & 90.7 & 95.3 & 100.0 & 102.5 & 107.6 & 108.0 & 107.7 \\
\hline \multicolumn{9}{|l|}{ Traffic } \\
\hline Local & 105.7 & 109.2 & 99.1 & 100.0 & 98.5 & 96.7 & 90.4 & \\
\hline Intercity & 70.1 & 73.9 & 99.1 & 100.0 & 98.5 & 96.7 & 90.4 & \\
\hline \multicolumn{9}{|l|}{ Total land to land } \\
\hline $\begin{array}{l}\text { Internet } \\
\text { Interne }\end{array}$ & $\begin{array}{c}95.4 \\
0.0\end{array}$ & $\begin{array}{c}99.0 \\
0.0\end{array}$ & $\begin{array}{l}99.1 \\
53.8\end{array}$ & $\begin{array}{l}100.0 \\
100.0\end{array}$ & $\begin{array}{c}98.5 \\
182.3\end{array}$ & $\begin{array}{c}96.7 \\
418.1\end{array}$ & $\begin{array}{r}90.4 \\
719.5\end{array}$ & $\begin{array}{c}\mathbf{8 5 . 0} \\
707.7\end{array}$ \\
\hline Land to mobile (LTM ) & 29.0 & 60.7 & 85.0 & 100.0 & 122.8 & 154.5 & 170.7 & 164.4 \\
\hline Mobile to land (MTL) & 33.2 & At & 90.6 & 100.0 & 118.5 & 132.4 & 140.4 & 136.7 \\
\hline \multicolumn{9}{|l|}{ International } \\
\hline interconnect & 61.4 & 71.4 & 80.4 & 100.0 & 118.1 & 127.8 & 136.6 & 141.4 \\
\hline Total & 76.4 & 84.7 & 93.1 & 100.0 & 109.2 & 129.8 & 150.2 & 144.8 \\
\hline Total output & 82.4 & 90.1 & 94.4 & 100.0 & 104.6 & 114.3 & 120.7 & 118.3 \\
\hline \multicolumn{9}{|l|}{ Traffic composition } \\
\hline Local & $70.9 \%$ & $66.1 \%$ & $54.6 \%$ & $51.3 \%$ & $46.3 \%$ & $38.2 \%$ & $30.9 \%$ & \\
\hline Intercity & $19.2 \%$ & $18.2 \%$ & $22.3 \%$ & $20.9 \%$ & $18.9 \%$ & $15.6 \%$ & $12.6 \%$ & \\
\hline \multicolumn{9}{|l|}{ Total land to land } \\
\hline (LTL) & $90.1 \%$ & $84.4 \%$ & $76.9 \%$ & $72.2 \%$ & $65.1 \%$ & $53.8 \%$ & $43.4 \%$ & $42.4 \%$ \\
\hline Internet & $0.0 \%$ & $0.0 \%$ & $4.4 \%$ & $7.5 \%$ & $12.6 \%$ & $24.2 \%$ & $36.0 \%$ & $36.8 \%$ \\
\hline Land to mobile (LTM ) & $3.1 \%$ & $5.9 \%$ & $7.5 \%$ & $8.2 \%$ & $9.3 \%$ & $9.8 \%$ & $9.4 \%$ & $9.4 \%$ \\
\hline Mobile to land (MTL) & $3.4 \%$ & $6.2 \%$ & $7.7 \%$ & $7.9 \%$ & $8.6 \%$ & $8.1 \%$ & $7.4 \%$ & $7.5 \%$ \\
\hline \multicolumn{9}{|l|}{ International } \\
\hline Total & $100.0 \%$ & $100.0 \%$ & $100.0 \%$ & $100.0 \%$ & $100.0 \%$ & $100.0 \%$ & $100.0 \%$ & $100.0 \%$ \\
\hline
\end{tabular}

Source: The Rates Review Committee 2002, Table 1.3 
Table 3. the Fixed Lines and the Mobile Markets 1995-2001

\begin{tabular}{|c|c|c|c|c|c|c|c|}
\hline & 1995 & 1996 & 1997 & 1998 & 1999 & 2000 & 2001 \\
\hline \multicolumn{8}{|l|}{ Subscribers (thousands) } \\
\hline Fixed line network & & 2,545 & 2,675 & 2,807 & 2,878 & 3,021 & 3,033 \\
\hline Mobile network & & 1,162 & 1,700 & 2,290 & 2,855 & 4,260 & 5,511 \\
\hline \multicolumn{8}{|l|}{ Traffic (mil. minutes) } \\
\hline Land to land (LTL) & 18,072 & 18,759 & 18,788 & 18,950 & 18,664 & 18,327 & 17,319 \\
\hline Land to mobile (LTM) & 628 & 1,314 & 1,384 & 2,163 & 2,656 & 3,341 & 3,775 \\
\hline Total fixed line origin & 18,700 & 20,073 & 20,172 & 21,113 & 21,320 & 21,668 & 21,094 \\
\hline Mobile to land (MTL) & 213 & 1,384 & 1,870 & 2,011 & 2,406 & 2,652 & 2,797 \\
\hline Mobile to mobile (MTM) & 56 & 676 & 1,161 & 1,798 & 2,928 & 4,917 & 7,352 \\
\hline Within networks & 38 & 515 & 858 & 1,361 & 2,046 & 3,338 & 5,007 \\
\hline Between networks & 19 & 160 & 302 & 437 & 882 & 1,579 & 2,345 \\
\hline Total mobile origin & 269 & 2,060 & 3,031 & 3,809 & 5,334 & 7,568 & 10,149 \\
\hline Total & 18,969 & 22,133 & 23,203 & 24,922 & 26,654 & 29,236 & 31,243 \\
\hline \multicolumn{8}{|l|}{$\underline{\text { Index }(1998=100)}$} \\
\hline \multicolumn{8}{|l|}{$\overline{\text { Subscribers }}$} \\
\hline$\overline{\text { Fixed line network }}$ & & 90.7 & 95.3 & 100.0 & 102.5 & 107.6 & 108.0 \\
\hline Mobile network & & 50.7 & 74.2 & 100.0 & 124.7 & 186.0 & 240.7 \\
\hline \multicolumn{8}{|l|}{ Traffic } \\
\hline Land to land (LTL) & 95.4 & 99.0 & 99.1 & 100.0 & 98.5 & 96.7 & 91.4 \\
\hline Land to mobile (LTM) & 29.0 & 60.7 & 64.0 & 100.0 & 122.8 & 154.5 & 174.5 \\
\hline Total fixed line origin & 88.6 & 95.1 & 95.5 & 100.0 & 101.0 & 102.6 & 99.9 \\
\hline Mobile to land (MTL) & 10.6 & 68.8 & 93.0 & 100.0 & 119.6 & 131.8 & 139.0 \\
\hline Mobile to mobile (MTM) & 3.1 & 37.6 & 64.5 & 100.0 & 162.9 & 273.5 & 408.9 \\
\hline Within networks & 2.8 & 37.9 & 63.1 & 100.0 & 150.4 & 245.3 & 368.0 \\
\hline Between networks & 4.2 & 36.6 & 69.2 & 100.0 & 201.7 & 361.1 & 536.2 \\
\hline Total mobile origin & 7.1 & 54.1 & 79.6 & 100.0 & 140.0 & 198.7 & 266.4 \\
\hline Total & 76.1 & 88.8 & 93.1 & 100.0 & 106.9 & 117.3 & 125.4 \\
\hline \multicolumn{8}{|l|}{ Traffic composition (\%) } \\
\hline$\overline{\text { Land to land (LTL) }}$ & $95.3 \%$ & $84.8 \%$ & $81.0 \%$ & $76.0 \%$ & $70.0 \%$ & $62.7 \%$ & $55.4 \%$ \\
\hline Land to mobile (LTM) & $3.3 \%$ & $5.9 \%$ & $6.0 \%$ & $8.7 \%$ & $10.0 \%$ & $11.4 \%$ & $12.1 \%$ \\
\hline Total fixed line origin & $98.6 \%$ & $90.7 \%$ & $86.9 \%$ & $84.7 \%$ & $80.0 \%$ & $74.1 \%$ & $67.5 \%$ \\
\hline Mobile to land (MTL) & $1.1 \%$ & $6.3 \%$ & $8.1 \%$ & $8.1 \%$ & $9.0 \%$ & $9.1 \%$ & $9.0 \%$ \\
\hline Mobile to mobile (MTM) & $0.3 \%$ & $3.1 \%$ & $5.0 \%$ & $7.2 \%$ & $11.0 \%$ & $16.8 \%$ & $23.5 \%$ \\
\hline Within networks & $0.2 \%$ & $2.3 \%$ & $3.7 \%$ & $5.5 \%$ & $7.7 \%$ & $11.4 \%$ & $16.0 \%$ \\
\hline Between networks & $0.1 \%$ & $0.7 \%$ & $1.3 \%$ & $1.8 \%$ & $3.3 \%$ & $5.4 \%$ & $7.5 \%$ \\
\hline Total mobile origin & $1.4 \%$ & $9.3 \%$ & $13.1 \%$ & $15.3 \%$ & $20.0 \%$ & $25.9 \%$ & $32.5 \%$ \\
\hline Total & $100.0 \%$ & $100.0 \%$ & $100.0 \%$ & $100.0 \%$ & $100.0 \%$ & $100.0 \%$ & $100.0 \%$ \\
\hline
\end{tabular}

Source: The Rates Review Committee 2002, Table 1.2 
Table 4: The Ad-Hoc Review Committees Main Recommendations

\begin{tabular}{|c|c|c|c|c|}
\hline Committee & I & II & III & IV \\
\hline Rate period & $1990-1993$ & $1994-1998$ & $1999-2002$ & $2003-2007$ \\
\hline Rate of return (\%) & 8.5 & 8.5 & 10.5 & 13.0 \\
\hline $\begin{array}{c}\text { Overall change in } \\
\text { tariffs (\%) }\end{array}$ & +15.0 & -10.0 & -10.5 & -5.5 \\
\hline X-factor proposed(\%) & $3.0-3.5$ & 6.5 & 7.0 & 3.5 \\
\hline X-factor approved (\%) & $3.0-3.5$ & $6.0-6.5(3.5)$ & $6.0(3.5)$ & 2.5 \\
\hline $\begin{array}{c}\text { Change in } \\
\text { fixed fee (\%) }\end{array}$ & -- & -- & +12.0 & +15.0 \\
\hline $\begin{array}{c}\text { Change in } \\
\text { price of calls (\%) }\end{array}$ & -- & -- & -32.0 & -23.4 \\
\hline $\begin{array}{c}\text { Interconnect rate-Peak } \\
\text { ( US cents) }\end{array}$ & -- & -- & $0.7-2.1$ & 1.0 \\
\hline
\end{tabular}


Table 5: Phone Rates Annual and CPI Change

( Mean and Standard Deviation) 1973-2002

\begin{tabular}{|c|c|c|c|c|c|}
\hline & \multicolumn{2}{|c|}{ Phone Rates } & \multicolumn{2}{c|}{ CPI } & $\begin{array}{c}\text { Number of } \\
\text { Annual } \\
\text { Rate Changes }\end{array}$ \\
\cline { 2 - 5 } & Mean & S.D. & Mean & S.D. & 2.0 \\
\hline $1973-1977$ & $-5.1 \%$ & $8.0 \%$ & $28.4 \%$ & $6.2 \%$ & 7.4 \\
$1977-1985$ & $-3.5 \%$ & $12.8 \%$ & $90.5 \%$ & $38.8 \%$ & 2.0 \\
$1985-1991$ & $0.2 \%$ & $8.0 \%$ & $20.7 \%$ & $9.2 \%$ & 1.3 \\
$1991-2003$ & $-5.6 \%$ & $3.5 \%$ & $6.7 \%$ & $4.2 \%$ & \\
\hline $1973-2003$ & $-3.9 \%$ & $8.2 \%$ & $34.5 \%$ & $39.6 \%$ & 3.1 \\
\hline
\end{tabular}


Table 6. Bezeq Cash Flow Report 1990- 2002

(millions of \$, XII.2002 prices)

\begin{tabular}{|c|c|c|c|c|c|c|}
\hline & \multicolumn{2}{|c|}{$1990-1996$} & \multicolumn{2}{|c|}{$1997-2002$} & \multicolumn{2}{|c|}{$1990-2002$} \\
\hline & Total & Average & Total & Average & Total & Average \\
\hline \multicolumn{7}{|l|}{ Sources: } \\
\hline Net Profit & 768 & 110 & -174 & -29 & 594 & 46 \\
\hline Losses of subsidiary companies & -128 & -18 & 437 & 73 & 309 & 24 \\
\hline Taxes & 457 & 65 & 144 & 24 & 601 & 46 \\
\hline Other (income) and expenses & 263 & 38 & 685 & 114 & 948 & 73 \\
\hline Operational profit (before taxes\} & 1361 & 194 & 1091 & 182 & 2452 & 189 \\
\hline Depreciation & 3222 & 460 & 2922 & 487 & 6144 & 473 \\
\hline Cash flow from current operation & 4583 & 655 & 4013 & 669 & 8596 & 661 \\
\hline \multicolumn{7}{|l|}{$\underline{\text { Uses }}$} \\
\hline Investment in fixed equipment & -3210 & -459 & -1414 & -236 & -4624 & -356 \\
\hline $\begin{array}{l}\text { Worker compensation (early } \\
\text { retirement) }\end{array}$ & -190 & -27 & -450 & -75 & -640 & -49 \\
\hline Investment in subsidiary companies & -15 & -2 & -270 & -45 & -285 & -22 \\
\hline Net debt repayment & -495 & -71 & -1512 & -252 & -2007 & -154 \\
\hline Other expenses & -62 & -9 & -36 & -6 & -97 & -7 \\
\hline Tax payments & -508 & -73 & -212 & -35 & -720 & -55 \\
\hline Dividends & -104 & -15 & -120 & -20 & -224 & -17 \\
\hline Total uses & -4583 & -655 & -4013 & -669 & -8596 & -661 \\
\hline
\end{tabular}

Source: The Rates Review Committee 2002, Table 1.6 
Table 7. The Welfare Effect of a Proportionate Markup vs. Ramsey Pricing - A Simulation

(The price elasticity of access $=0.1$, price elasticity of traffic $=0.5$ )

\begin{tabular}{|c|c|c|c|c|c|c|c|c|c|}
\hline & \multicolumn{3}{|c|}{ Proportionate markup } & \multicolumn{3}{|c|}{ Ramsey pricing } & \multicolumn{3}{|c|}{ Committee proposal } \\
\hline & Access & Traffic & Total & Access & Traffic & Total & Access & Traffic & Total \\
\hline \multicolumn{10}{|l|}{1998 Actual } \\
\hline$\overline{\text { Output }}$ & 2,800 & 31,400 & & 2,800 & 31,400 & & 2,800 & 31,400 & \\
\hline Revenue (mil. \$) & 353 & 720 & 1,072 & 353 & 720 & 1,072 & 353 & 720 & 1,072 \\
\hline Direct cost (mil. \$) & 380 & 169 & 549 & 380 & 169 & 549 & 380 & 169 & 549 \\
\hline $\begin{array}{l}\text { Common costs } \\
(\mathrm{mil} . \$)\end{array}$ & & & 296 & & & 296 & & & 296 \\
\hline Average rate & 126 & 2.29 & & 126 & 2.29 & & 126 & 2.29 & \\
\hline Average direct cost & 136 & 0.54 & & 136 & 0.54 & & 136 & 0.54 & \\
\hline Markup (\%) & $-7.8 \%$ & $76.5 \%$ & & $-7.8 \%$ & $76.5 \%$ & & $-7.8 \%$ & $76.5 \%$ & \\
\hline \multicolumn{10}{|l|}{ Proposal } \\
\hline$\overline{\text { Markup (\%) }}$ & $31.2 \%$ & $31.2 \%$ & $31.2 \%$ & $42.6 \%$ & $8.5 \%$ & & $0.0 \%$ & $56.1 \%$ & \\
\hline Average rate & 197 & 0.78 & & 236 & 0.59 & & 136 & 1.23 & \\
\hline Output & 2,677 & 53,783 & & 2,629 & 62,007 & & 2,779 & 42,935 & \\
\hline Revenue (mil. \$) & 528 & 420 & 948 & 621 & 365 & 986 & 377 & 526 & 904 \\
\hline Direct cost (mil. \$) & 363 & 289 & 653 & 357 & 333 & 690 & 377 & 231 & 608 \\
\hline $\begin{array}{l}\text { Common costs } \\
(\mathrm{mil} . \$)\end{array}$ & 165 & 131 & 296 & 265 & 31 & 296 & 0 & 296 & 296 \\
\hline \multicolumn{10}{|l|}{ Change } \\
\hline Average rate $(\%)$ & $56.6 \%$ & $-65.9 \%$ & & $87.7 \%$ & $-74.4 \%$ & & $7.8 \%$ & $-46.5 \%$ & \\
\hline Revenue (mil. \$) & 175 & -300 & -124 & 269 & -355 & -87 & 25 & -193 & -169 \\
\hline $\begin{array}{l}\text { Consumer surplus } \\
\text { (mil. \$) }\end{array}$ & -195 & 599 & 404 & -299 & 711 & 412 & -27 & 387 & 359 \\
\hline
\end{tabular}

Comments:

1. Access is measured in thousands of subscribers and traffic is measured in millions of minutes. The access average rate is the annual fixed fee measured in dollars (and so are the average direct costs of access).

Traffic is measured in million of minutes and the average rate of traffic is the rate per minute measured in cents.

2. The markup is measured relative to the average price $[\mathrm{m}=1-(\mathrm{c} / \mathrm{p})]$. 
Figure 1. International Traffic 1993 - 2001

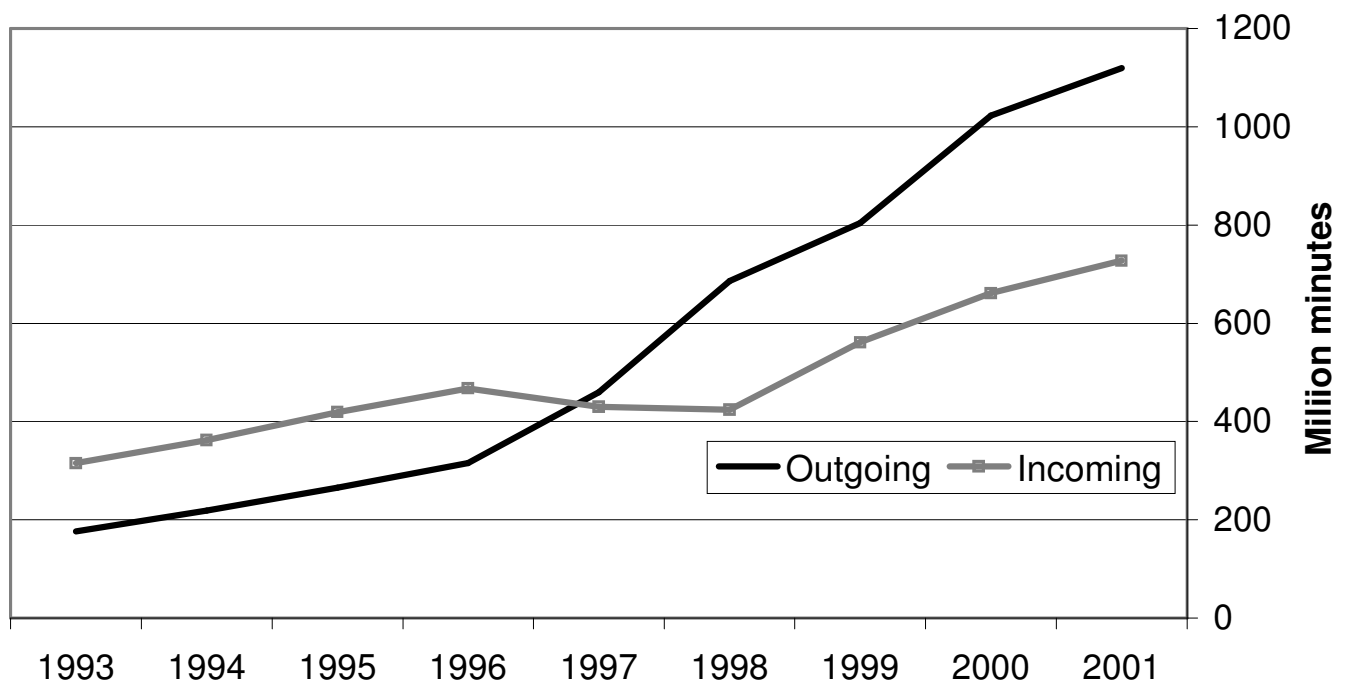

Source: The Rates Review Committee 2002, p.4

Figure 2.Price Indices Fixed lines vs. Mobile 1997-2003

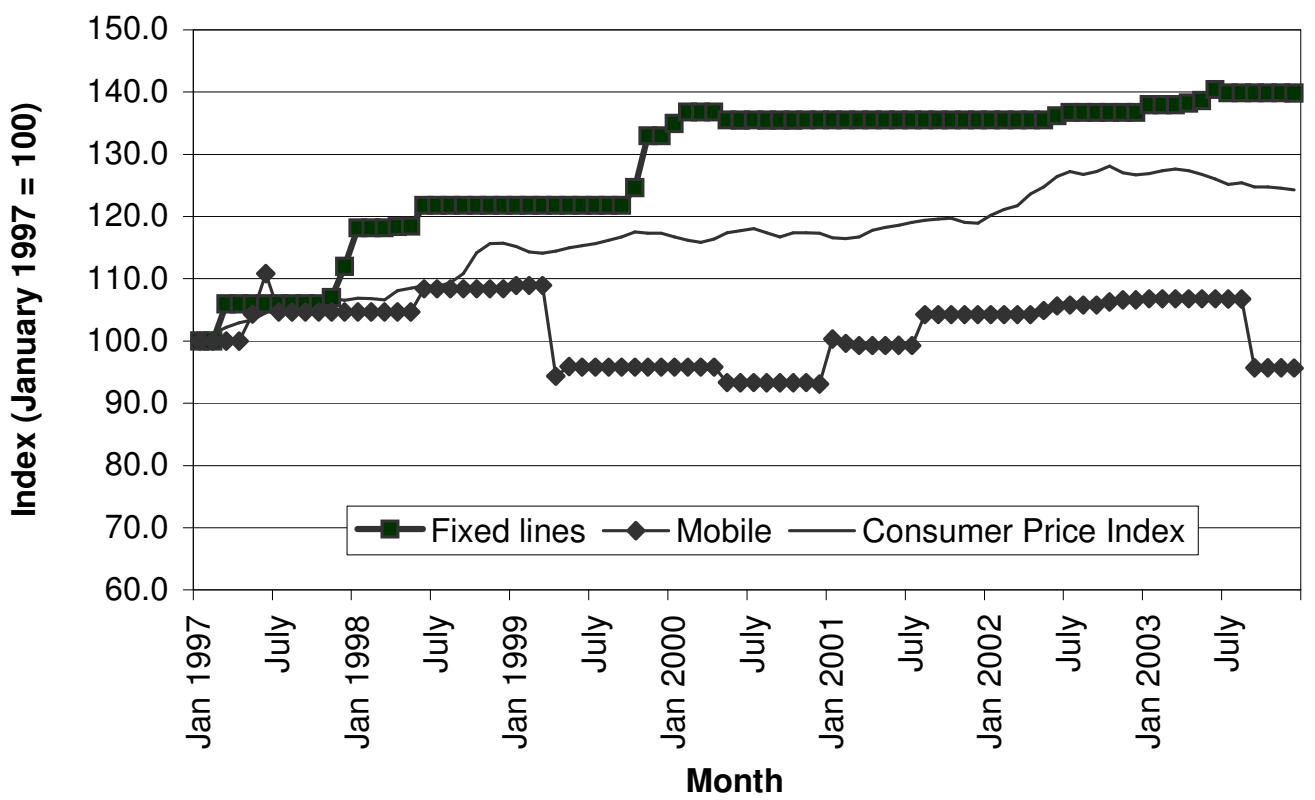


Figure 3. International Call Rates Indices- Nominal and Real $($ January $1990=100)$

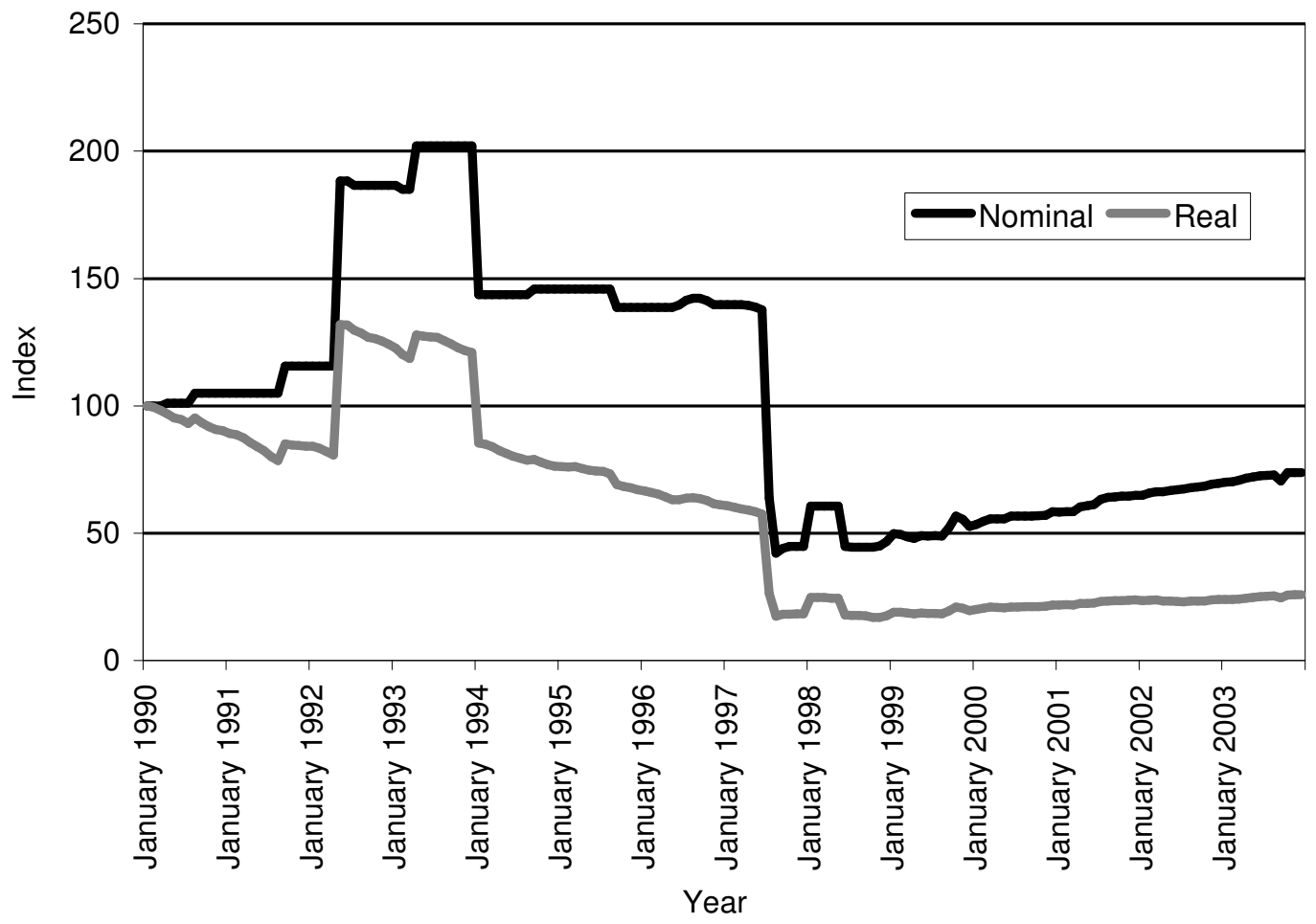


Figure 4a. Phone Rates in Europe and Israel 1990, 2000 (in cents)

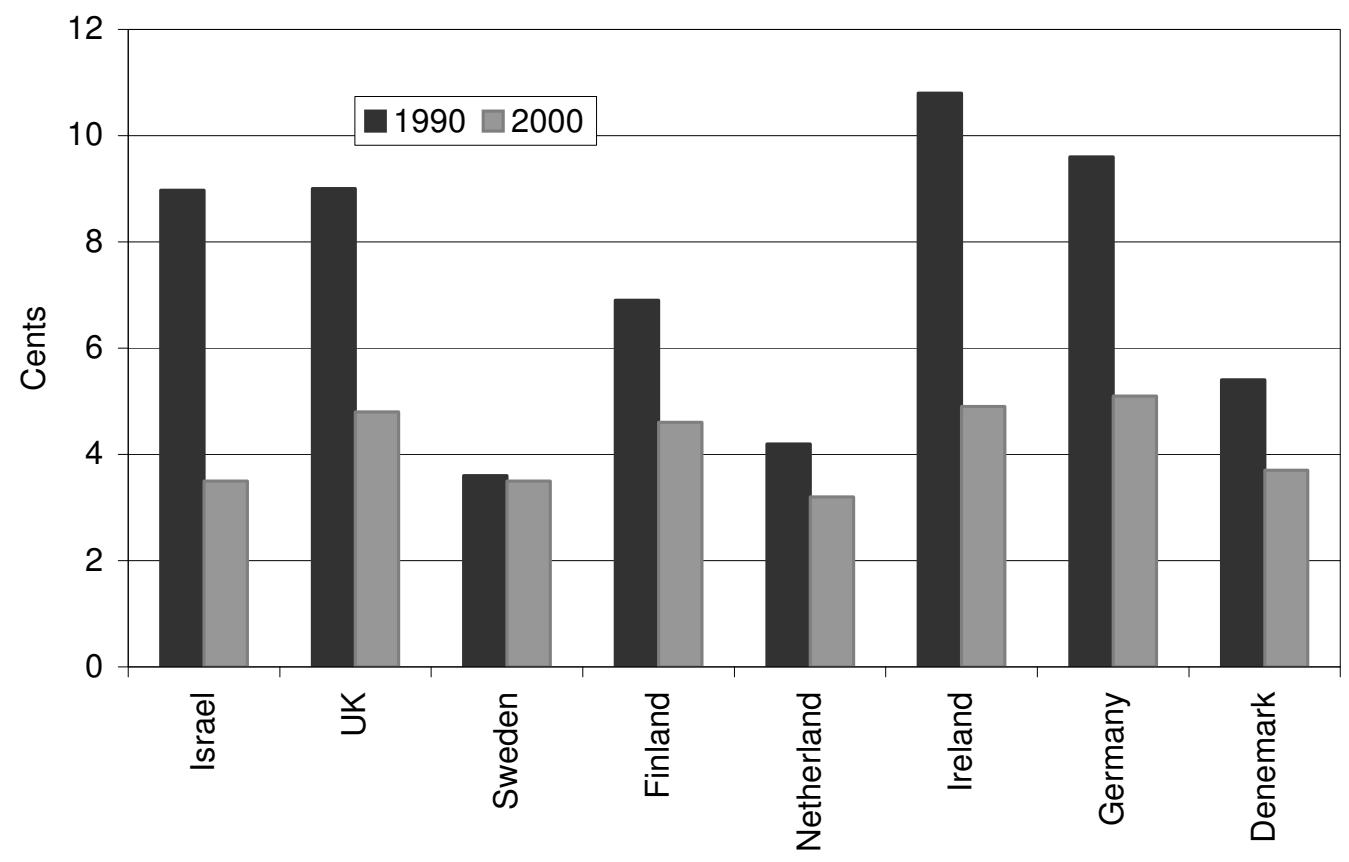

Figure 4b. Monthly Fee in Europe and Israel 1990, 2000 ( in dollars)

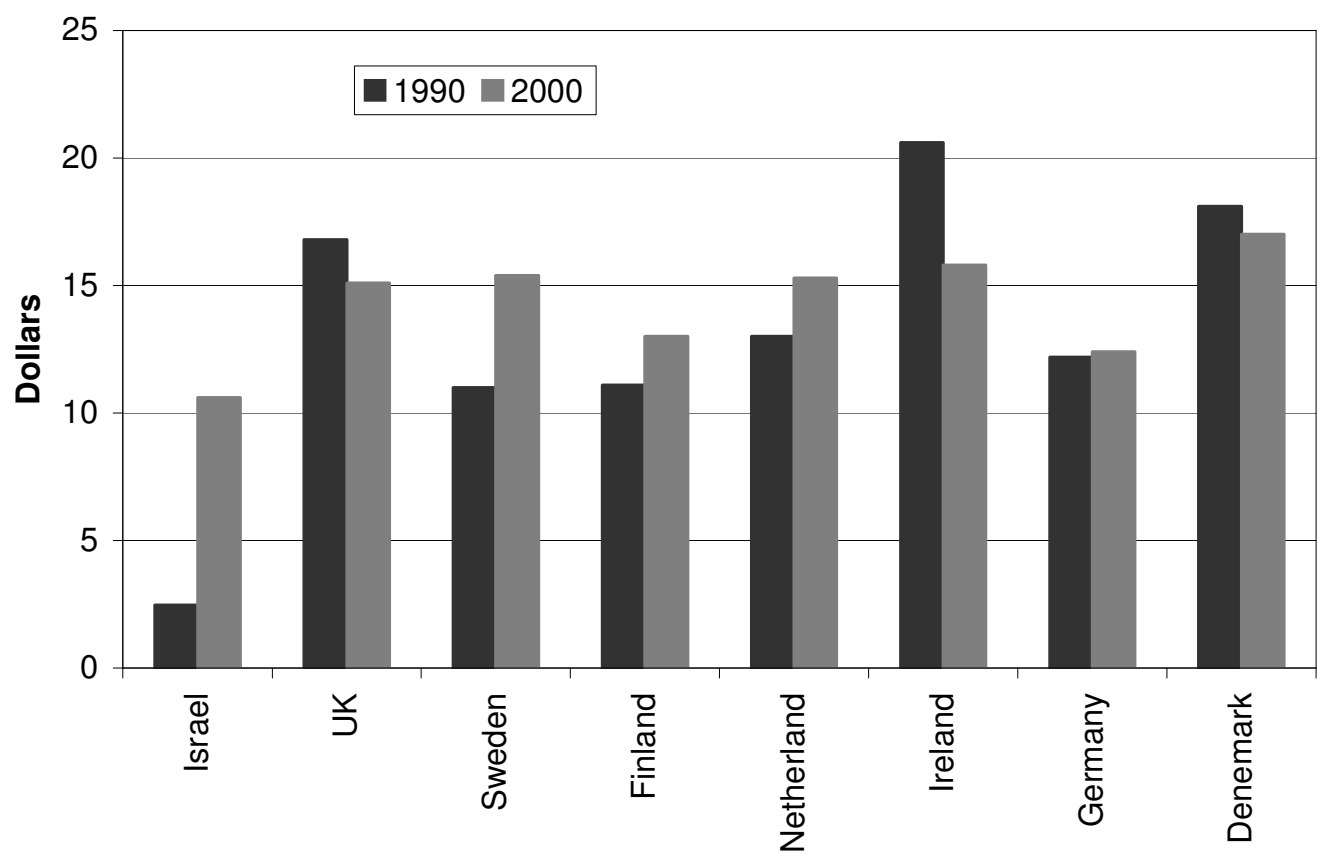


Figure 5a. Bezeq Income and Expenditures 1984-1996 (mill \$)

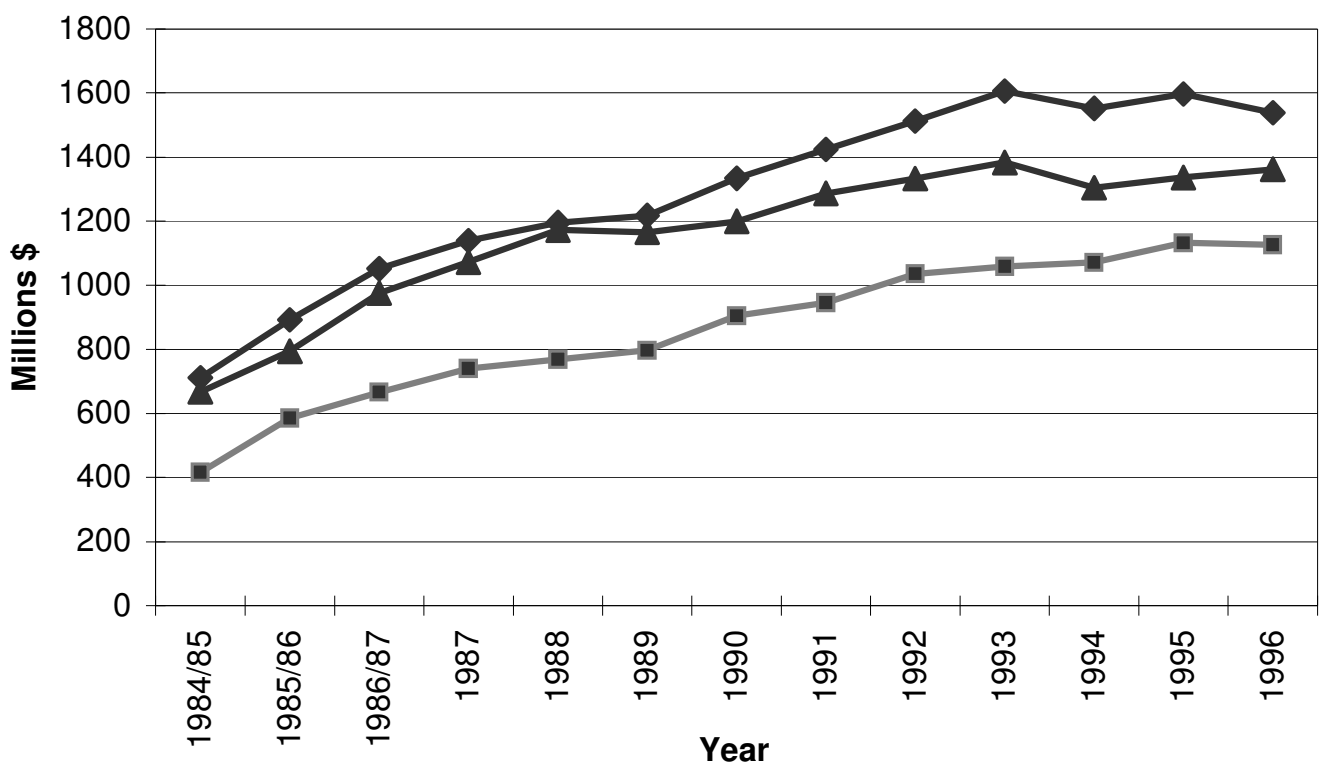

$\longrightarrow$-Income from domestic services $\neg$ Total income $\neg$ Total expenditures

Figure 5b. Bezeq Actual and Normative Profits 1984-1996 (mill \$)

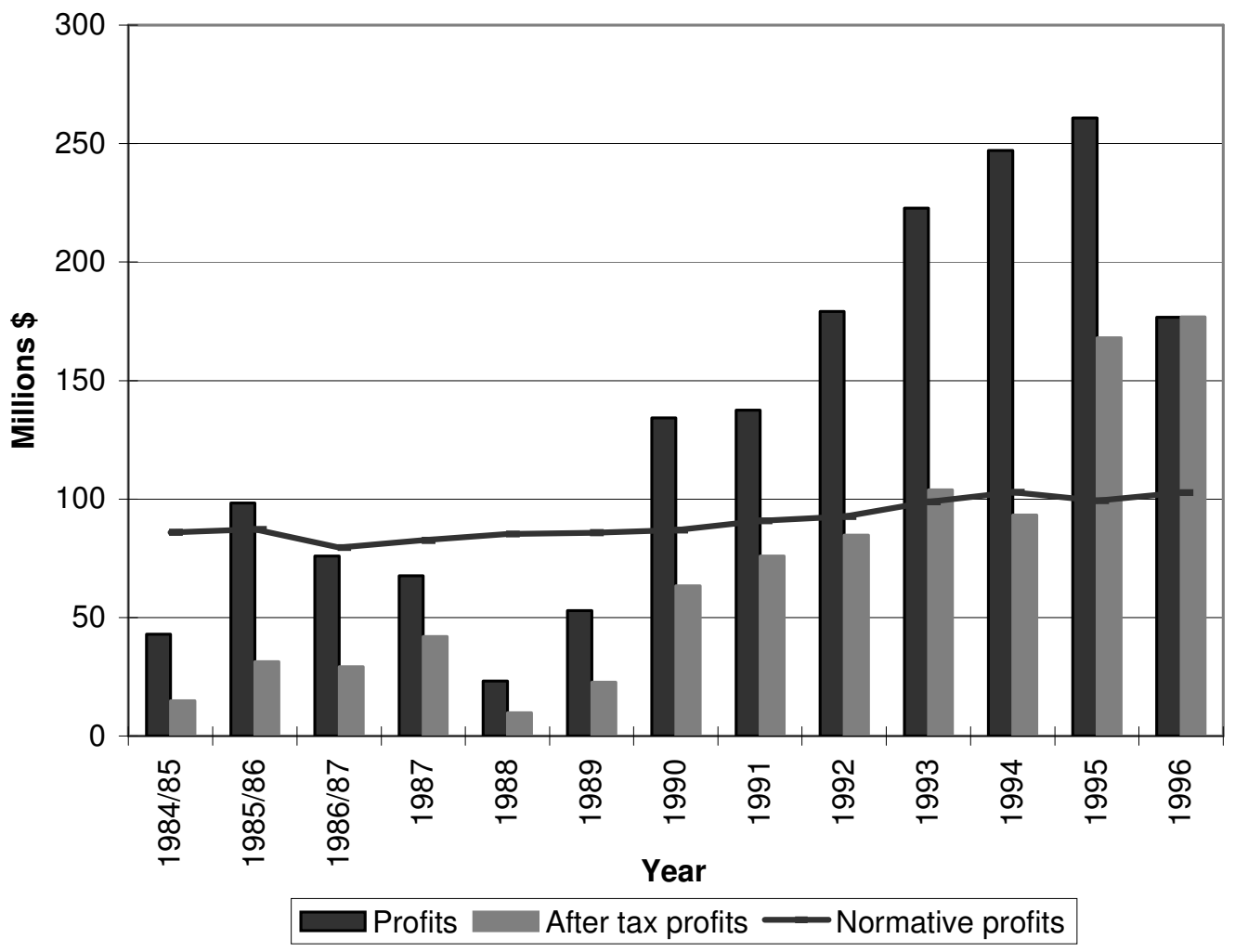


Figure 6. Bezeq D-O Profitability 1994-2002 (Mill \$)

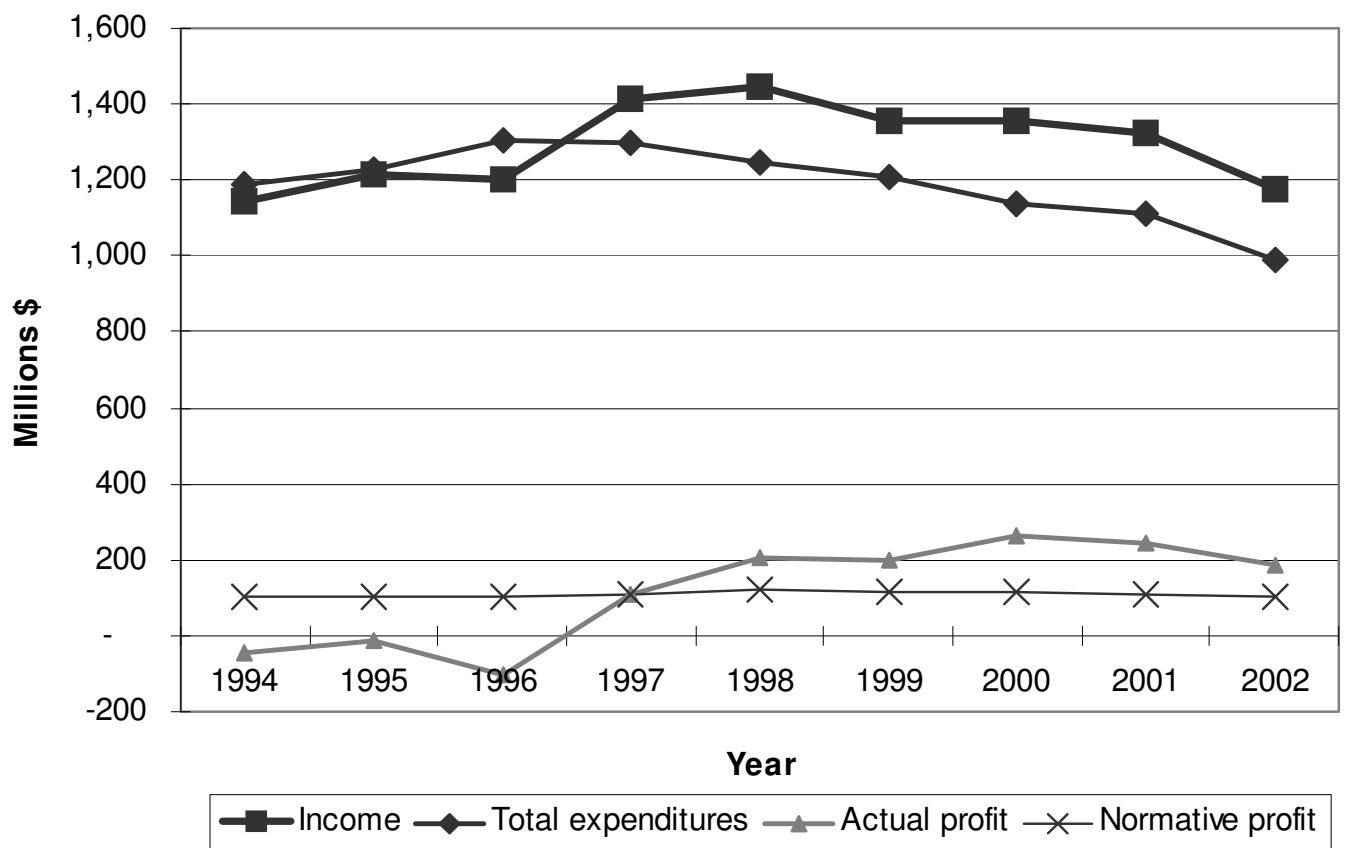

Figure 7. Bezeq Expenditures 1984 - 1996

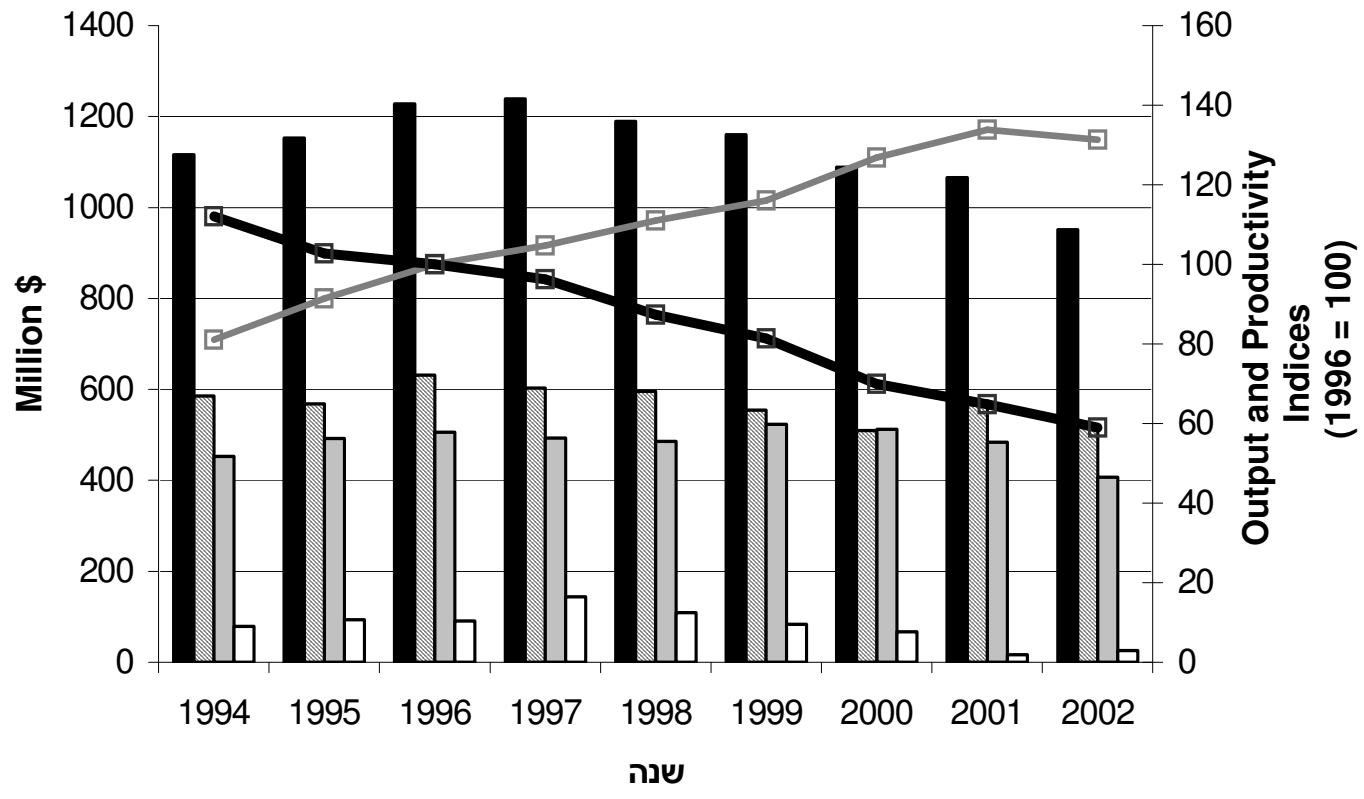
Total Expenditures
Total Operating Costs
$\square$ Depreciation
$\square$ Finance Charges
$\rightarrow$ Output Index
$\rightarrow$ Cost per unit Index 
Figure 8. Bezeq D-O Expenditures 1994 - 2002
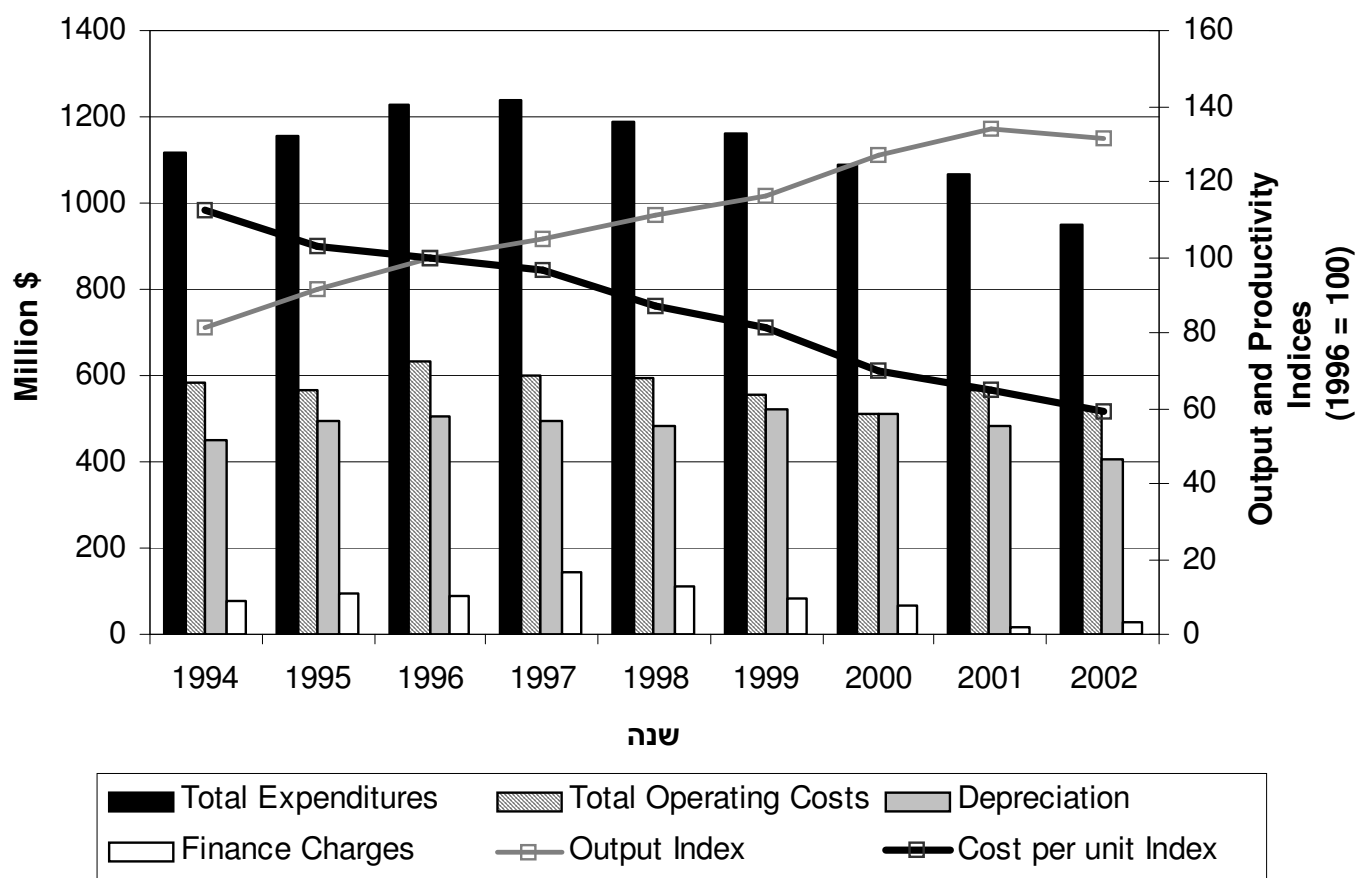

Figure 9.Wage and Employment Indices - Bezeq 1985-2001

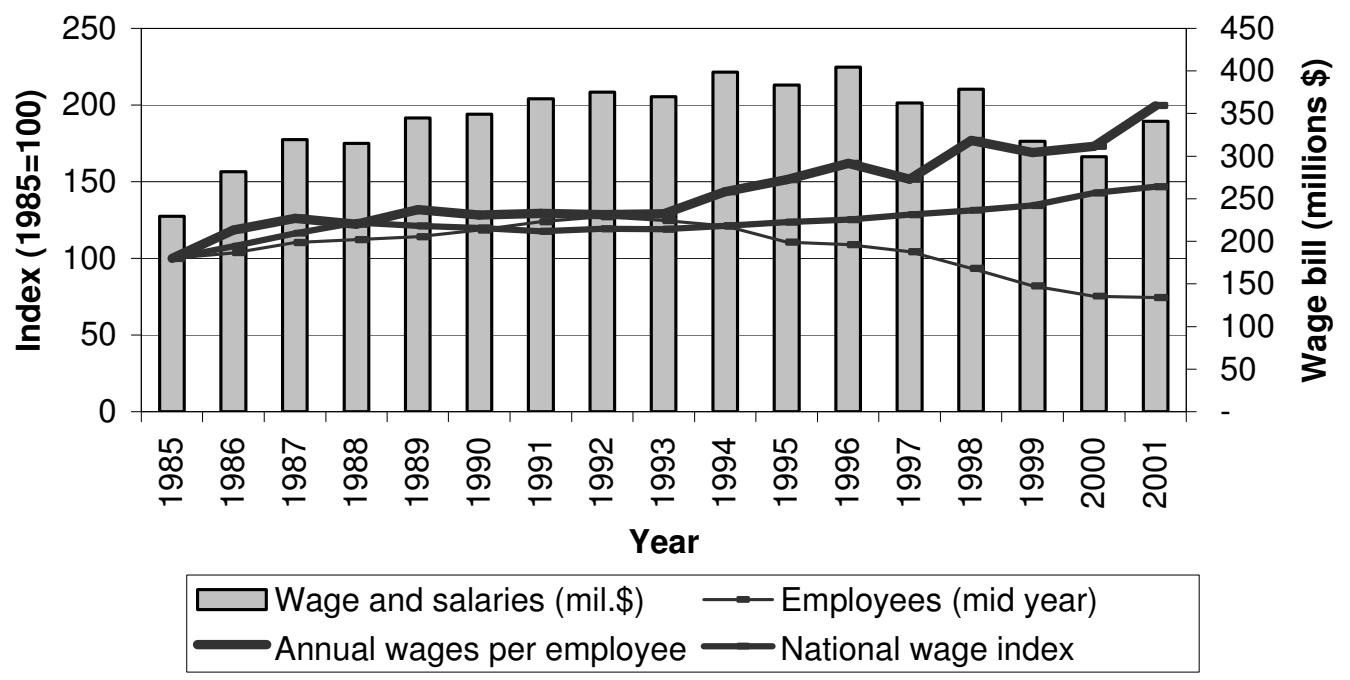


Figure 10. Bezeq's Normative vs. Actual Costs 1998 - 2002

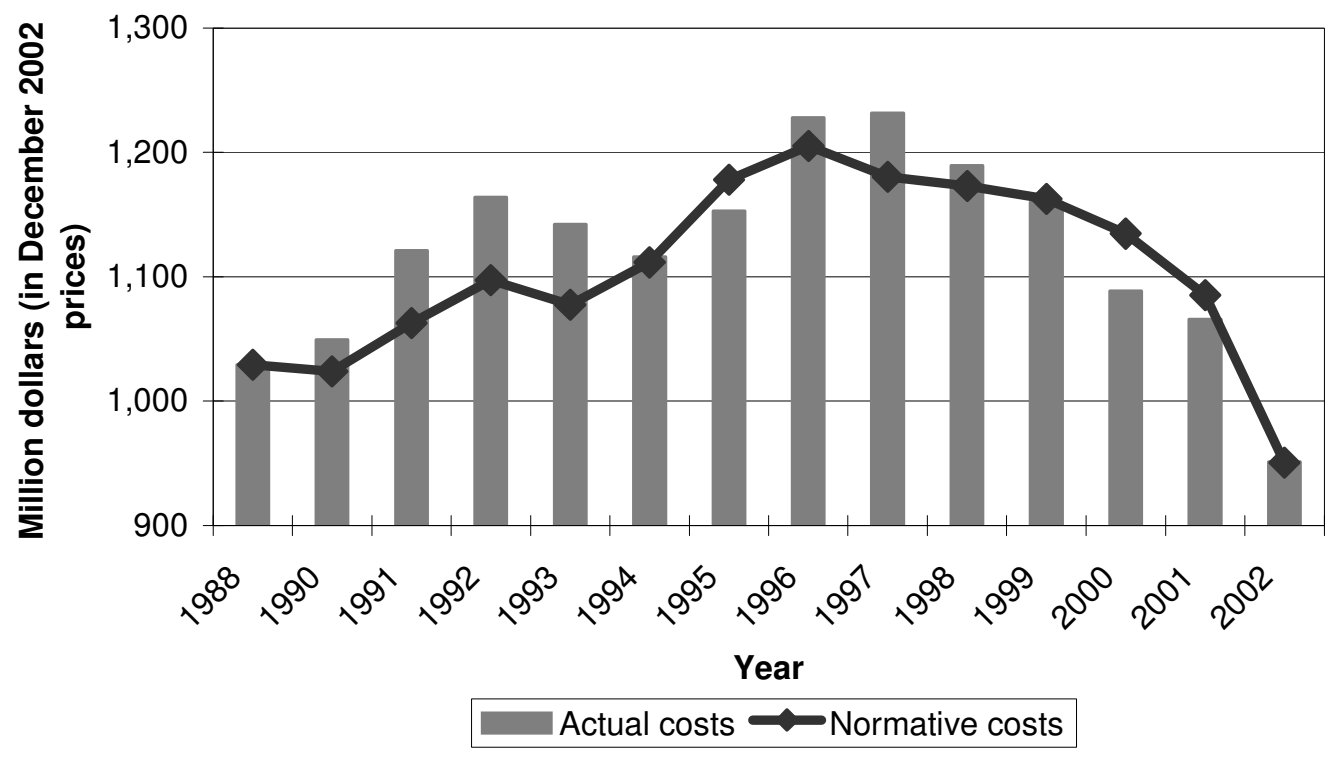

